\title{
Chemokine isoforms and processing in inflammation and immunity
}

Paul Proost ${ }^{\mathrm{a}}{ }^{1}$, Sofie Struyf ${ }^{\mathrm{a}}$, Jo Van Damme ${ }^{\mathrm{a}, 2}$, Pierre Fiten ${ }^{\mathrm{b}}$, Estefania Ugarte-Berzal ${ }^{\mathrm{b}}$ and Ghislain Opdenakker ${ }^{\mathrm{b}}$

a Laboratory of Molecular Immunology and 'baboratory of Immunobiology, Department of Microbiology and Immunology, Rega Institute for Medical Research, KU Leuven, University of Leuven, Herestraat 49, B-3000 Leuven, Belgium

${ }^{1}$ Equally contributed

${ }^{2}$ Corresponding_author

Email addresses:

paul.proost@kuleuven.be

sofie.struyf@kuleuven.be

jo.vandamme@kuleuven.be

estefania.ugarteberzal@kuleuven.be

pierre.fiten@kuleuven.be

ghislain.opdenakker@kuleuven.be

highlights:

CD26 regulates leukocyte migration to arthritic joints through chemokine truncation.

Chemokine cleavage by matrix metalloproteases affects autoimmunity.

Chemokine glycosylation protects against proteolysis.

Chemokines interact with glycosaminoglycans in inflammation.

Peptidylarginine deiminases, active in autoimmune diseases, also citrullinate chemokines. 


\begin{abstract}
The first dimension of chemokine heterogeneity is reflected by their discovery and purification as natural proteins. Each of those chemokines attracted a specific inflammatory leukocyte type. With the introduction of genomic technologies, a second wave of chemokine heterogeneity was established by the discovery of putative chemokine-like sequences and by demonstrating chemotactic activity of the gene products in physiological leukocyte homing. In the postgenomic era, the third dimension of chemokine heterogeneity is the description of posttranslational modifications on most chemokines. Proteolysis of chemokines, for instance by dipeptidyl peptidase IV (DPP IV/CD26) and by matrix metalloproteinases (MMPs) is already well established as a biological control mechanism to activate, potentiate, dampen or abrogate chemokine activities. Other posttranslational modifications are less known. Theoretical $\mathrm{N}$-linked and O-linked attachment sites for chemokine glycosylation were searched with bio-informatic tools and it was found that most chemokines are not glycosylated. These findings are corroborated with a low number of experimental studies demonstrating $\mathrm{N}$ - or O-glycosylation of natural chemokine ligands. Because attached oligosaccharides protect proteins against proteolytic degradation, their absence may explain the fast turnover of chemokines in the protease-rich environments of infection and inflammation. All chemokines interact with $\mathrm{G}$ protein-coupled receptors (GPCRs) and glycosaminoglycans (GAGs). Whether lectin-like GAG-binding induces cellular signaling is not clear, but these interactions are important for leukocyte migration and have already been exploited to reduce inflammation. In addition to selective proteolysis, citrullination and nitration/nitrosylation are being added as biologically relevant modifications contributing to functional chemokine heterogeneity. Resulting chemokine isoforms with reduced affinity for GPCRs reduce leukocyte migration in various models of inflammation. Here, these third dimension modifications are compared, with reflections on the biological and pathological contexts in which these posttranslational modifications take place and contribute to the repertoire of chemokine functions and with an emphasis on autoimmune diseases.
\end{abstract}

keywords: chemokine, protease, CD26, citrulline, glycosylation, nitration 


\section{Proteolysis of chemokines}

\subsection{Dipeptidyl peptidase IV/CD26}

Dipeptidyl peptidase IV (DPP IV), alias CD26 is a serine type protease that cleaves off dipeptides from the $\mathrm{NH}_{2}$-terminus of peptide chains if the penultimate residue is Pro or Ala, though sometimes, other amino acids may be accepted [1,2]. Natural substrates of CD26 comprise peptide hormones, vasoactive peptides, neuropeptides, chemotactic cytokines (chemokines) and a few cytokines and growth factors [3-5]. Remarkably, many substrates activate G protein-coupled receptors (GPCRs), although their structural characteristics are quite diverse [4]. Inhibitors against CD26 were commercialized because the protease is a key regulator of glucose metabolism through cleavage of incretin hormones, but hematopoiesis, immunity, and cancer biology are also influenced by CD26. The role of CD26 within the immune system is a combination of its exopeptidase activity and its interactions with different molecules. This enables CD26 to regulate hematopoietic progenitor/stem cell (HPC/HSC) homing, engraftment, and growth; to serve as a costimulatory molecule influencing $T$ cell activity [1,3]; to influence anti-viral defense (human immunodeficiency virus and hepatitis $C$ virus) [1,6]; and to modulate leukocyte chemotaxis and mobilization [2-3,7].

\subsubsection{CD26 EXPRESSION}

Cell-bound CD26 is rather ubiquitously expressed on leukocytes, fibroblasts, and epithelial, mesothelial, and endothelial cells and can be detected in placenta, pancreas, liver, gall bladder, intestine, kidney, and prostate $[1,4]$. Furthermore, modulated expression of CD26 on tumor cells has been reported [8]. Apart from its expression in solid tissues-either normal or malignant-CD26 is expressed by several leukocyte types, e.g., T cells, activated B cells, dendritic cells, NK cells and CD34+ progenitor cells $[1,4,9]$. CD26 was characterized originally as a T cell subset marker, present on $10-60 \%$ of resting T cells [10]. Systematically higher CD26 levels were detected on CD4+ T cells than on CD8+ T cells [10]. CD26 expression increases after T cell activation [11] and therefore, is a suitable marker for activated T cells. T cells expressing high levels of CD26, constitute a subpopulation of CD45RO+ memory T cells and produce IL-2 in response to mitogenic or alloantigenic stimulation [12]. Those CD26 high subsets are the only CD4+ cells that respond to recall antigens, induce synthesis of IgG in B cells, and activate MHC-restricted cytotoxic T cells [12]. In addition to the membrane-bound protease, a soluble form of CD26 exists, which is enzymatically fully active and occurs at high levels in seminal fluid; lower amounts are detected in plasma, urine, synovial fluid and cerebrospinal fluid [12]. For a long time, the enzyme releasing CD26 from cellular surfaces remained unknown. However, Röhrborn et al. [13] recently demonstrated that several MMPs can cleave CD26, setting free the extracellular catalytic domain. CD26 and its substrates highlighted in this review, namely chemokines, are often expressed under similar conditions. For instance in autoimmune diseases, such as multiple sclerosis (MS), Graves' disease, and rheumatoid arthritis (RA), large numbers of CD26+ T cells have been detected in peripheral blood and/or inflamed tissues of patients [14-17].

\subsubsection{CD26 INHIBITORS}

Currently, at least 11 CD26 inhibitors have been approved by either the U.S. Food and Drug Administration, the European Medicines Agency or other Asian Agencies [18]. CD26 inhibitors are applied in diabetes to inhibit the proteolytic inactivation of the insulinotropic hormones (incretins), glucose-dependent insulinotropic polypeptide or gastric inhibitory polypeptide (GIP), and glucagonlike peptide-1 (GLP-1) and to normalize glucose homeostasis [1,18-19]. GIP and GLP-1 are released in response to food in the intestinal lumen and stimulate the production and release of insulin. Following evidence in animal models of type 2 diabetes for the therapeutic benefit of CD26 inhibitors stabilizing the incretins in vivo, CD26 inhibitors and CD26-resistant GLP-1 analogs are now approved therapeutics for diabetic patients. By prolonging the incretin effect, these therapeutics increase glucose tolerance. In addition, CD26 inhibitors (e.g., sitagliptin) improve pancreatic islet cell function in patients with type 2 diabetes, as prolonged activation of the $\beta$-cell GIP receptor induces 
proliferation and reduces apoptosis [20]. Currently, sitagliptin is also considered as add-on therapy for treating patients with autoimmune (type 1) diabetes, as inhibition of CD26 and its T cellactivating properties may preserve or increase $\beta$-cell mass [21]. The effect of CD26 inhibitors has also been evaluated in other pathologies in which CD26 is considered important. For instance, sitagliptin treatment was shown to reduce melanoma growth in mice because of delayed chemokine processing [22]. The latter study explores the possibility of therapeutic intervention blocking chemokine processing by CD26. Indeed, chemokines are very good substrates for CD26 (rapidly cleaved), as is discussed below. Recently, the effect of CD26 inhibitors on the incidence risk of autoimmune diseases, such as RA, systemic lupus erythematosus (SLE), psoriasis, MS and inflammatory bowel disease (IBD), was evaluated in a large cohort of patients (>200000) with type 2 diabetes [23]. The incidence risk of RA and composite autoimmune diseases was lower in the patients on CD26 inhibitor + metformin therapy, compared to patients treated with metformin only.

\subsubsection{CD26 AND ITS CHEMOKINE SUBSTRATES IN RHEUMATOID ARTHRITIS}

1.1.3.1. Functions of chemokines present in RA

RA was one of the first pathologies in which chemokine/chemokine receptor inhibitors were tested. In particular, the CC chemokine receptors CCR1, CCR2 and CCR5 and their ligands were targeted by small molecule antagonists or neutralizing antibodies, because increased expression was documented in RA [24-25]. The aim was to inhibit leukocyte recruitment (activated monocytes, $T$ cells, neutrophils, osteoclasts) to the inflamed joint in response to increased CCR1 ligand expression (CCL3/CCL3L1, CCL5, CCL15 and CCL23). CCR2 is a prominent monocyte/macrophage receptor. Its best-known ligand is CCL2. However, CCR2 also interacts with CCL7, CCL8, CCL13 and CCL16. CCR5 is expressed on synovial macrophages and T lymphocytes and is activated by CCL3/CCL3L1, CCL4, CCL5, CCL7 and CCL8. CCR1, CCR2 and CCR5 ligands typically are chemokines attracting leukocytes to the inflamed joints, but also homeostatic chemokines, such as CCL19 are involved in RA pathology. CCL19 is expressed by fibroblasts and macrophages in affected synovia and its concentration in plasma predicts progression and response to therapy [24]. The first chemokine detected in RA synovial fluid was CXCL8 and other CXCR2 ligands were later on shown to be important neutrophil attractants in the arthritic joints [26-27]. The homeostatic B cell chemoattractant CXCL13 has also been identified as a marker of disease activity in RA and is expressed by a subpopulation of CD4+ T helper cells $[24,28]$. T cell entry in the synovium is mediated by CXCR3 and CXCR4. Macrophages, fibroblasts, and endothelial cells within the synovial membrane express the CXCR4 ligand CXCL12. CXCR3 has several ligands that act as important chemoattractants of activated NK, NKT and T cells, of which CXCL9 and CXCL10 are highly upregulated in RA synovial fluid [29,30]. In early disease, CXCL10 has been proposed to be the best chemokine biomarker in plasma of RA patients [31]. Genome-wide association studies identified "CCR6DNP" as an important risk factor for RA [32]. It was shown that this non-coding variant regulates CCR6 expression and Th17 cytokine production [32]. Indeed, CCL20, the ligand for CCR6 is an important attractant of Th17 cells, subsets of B cells and dendritic cells and is expressed by synoviocytes, neutrophils and Th17 cells in inflamed joints [33]. In addition to attraction of leukocytes, several of those chemokines affect angiogenesis, which also contributes to RA pathology. CXCL12, acting through CXCR4 and atypical chemokine receptor 3 (ACKR3), and all CXCR2 ligands favor angiogenesis whereas the CXCR3 ligands inhibit angiogenesis $[27,34]$. In addition to leukocytes and endothelial cells also synovial fibroblasts, fibroblast-like synoviocytes and osteoclasts are cellular targets of chemokines in RA.

The original clinical trials with chemokine or chemokine receptor inhibitors, targeting CCR1, CCR2 and CCR5 in RA were disappointing, despite promising pre-clinical studies [24,27]. Those studies aimed at decreasing monocyte/macrophage infiltration of the joints. It is well accepted that these cells are increased in number in clinically affected joints and that their numbers correlate with 
clinical signs and symptoms [24]. Several explanations are possible for the failure of the RA clinical trials in which chemokines were tested: too low affinity of the inhibiting molecules for the target, too limited in vivo coverage of the target, high redundancy between the monocyte-attracting chemokines, limited concordance between the chemokine system in rodents and humans, off-target inhibition (e.g., CCR5 is expressed on $\mathrm{T}_{\text {reg }}$ cells), limited knowledge on the molecular appearance of detected chemokines (agonistic vs antagonistic isoforms), etc.

Interestingly, CXCL10 proved to be a good chemokine target in RA. Significant therapeutic effects were reported for a phase II clinical trial with MDX-1100, a neutralizing anti-CXCL10 monoclonal antibody [35]. Further research is needed to reveal the working mechanism behind this inhibition. A phase II clinical trial with the second generation CCR1 antagonist (CCX354) was also efficient [36]. Therefore chemokine-targeting is still a valuable approach to treat RA and more recently identified chemokine targets (CXCL12/CXCR4, CXCL12/ACKR3, CXCL13/CXCR5 and CCL20/CCR6) certainly merit further investigation.

\subsubsection{CD26 and RA}

Literature reports are not fully congruent with regard to CD26 expression or DPP IV activity in RA, but some of the contradictions can probably be explained by differential sialylation of $C D 26$, which affects its enzymatic activity and might also affect its recognition by monoclonal antibodies [15,37]. Serum levels of soluble CD26 (measured by ELISA) were similar in RA compared to controls; however, DPP IV specific activity was significantly reduced in sera from RA patients [37-38]. It was demonstrated that CD26 is hypersialylated in RA serum and after desialylation its specific activity was restored to close to control values, suggesting that differential glycosylation of the enzyme might affect its specific activity in RA patients [37]. Enhanced CD26 density on circulating monocytes and CD4(+) T lymphocytes in active RA has been reported [39]. Indeed, several groups reported higher percentages of peripheral blood CD26+ CD4+ T cells in patients with active disease than in inactive RA and control subjects [15-17]. However, membrane or soluble CD26 values did not correlate with disease activity or response to methotrexate treatment [39-41]. Mavropoulos et al. reported that anti-tumor necrosis factor-alpha (TNF- $\alpha$ ) therapy augments DPP IV activity in serum concordant with a significant improvement of the disease activity score (DAS28) [42]. Specifically, $T$ cells with high levels of CD26 antigen and expressing CD45R0 preferentially migrate into the rheumatoid synovium $[15,17]$. In the synovial membrane DPP IV activity was significantly higher in the RA group than in osteoarthritis [43], which is opposed to DPP IV activity in synovial fluid [44]. Finally, systemic inhibition of CD26 in diabetic patients decreased the incidence of RA, but also of other autoimmune diseases [23]. The mechanism behind this improvement has not yet been identified.

\subsubsection{Interaction between CD26 and chemokines in RA}

A rather unexpected interaction between CD26 and CCR6 was revealed in a genome-wide association study of a Han Chinese population. Two SNPs (rs12617656 in DPP4, rs1854853 in CCR6) were genotyped and a significant multiplicative interaction between DPP4 and CCR6 was observed in RA. The epistatic effect was stronger in anti-citrullinated peptide/protein antibodies (ACPA)-positive RA [45]. However, in contrast to many other chemokines, CCL20, the ligand of CCR6, is not a substrate of CD26. Well-known chemokine substrates of CD26 detected in RA include the CCR1/CCR5 ligands CCL3L1 and CCL5, the CXCR3 ligands CXCL9 and CXCL10 and the CXCR4 ligand CXCL12. The biological effect of CD26 processing is different for these chemokine substrates (Table 1) $[2,46] . \mathrm{NH}_{2}$-terminal cleavage of CCL3L1 results in enhanced monocyte and lymphocyte chemotactic activity because of more efficient receptor activation. Cleavage of CCL5 by CD26 
reduces its monocyte chemotactic potency (decreased CCR1 activation), but increases its lymphocyte attractant activity (increased CCR5 recognition). The CXCR3 ligands are inactivated by CD26 in terms of lymphocyte attracting capacity and even become CXCR3 antagonists, but retain their angiostatic activity. CXCL12 is the best chemokine substrate of CD26 in terms of conversion velocity [47]. Truncation of CXCL12 by CD26 reduces its ACKR3 and CXCR4-dependent activity on endothelial cells and lymphocytes [48]. Moreover, in CD26-deficient mice increased levels of active CXCL12 were associated increased numbers of CXCR4 positive cells infiltrating the arthritis joints causing higher disease severity in the antigen-induced arthritis model [49]. Furthermore, some chemokines (e.g. CCL14) become potential CD26 substrates after a preceding cleavage by a different protease that first removes some $\mathrm{NH}_{2}$-terminal residues. Indeed, after cleavage of CCL14(1-74) by plasmin, CCL14(9-74) is effectively truncated by CD26 into inactive CCL14(11-74) [50]. Expression of CCL14 in RA synovium is detected, but this chemokine is not specifically upregulated in RA compared to other arthritic pathologies [51].

In view of the diverse biological outcomes of chemokine cleavage by CD26, it is difficult to make a general conclusion whether CD26 acts pro- or anti-inflammatory by cleaving chemokines in the inflamed joints. From the successful clinical trials, we can deduce that especially CCR1 and CXCR3 are important chemokine receptors in perpetuating disease. Neutralization of the CXCR3 ligand CXCL10 improved disease in RA patients. CD26 inhibits the pro-inflammatory activity of CXCL10 as it causes down-regulation of the lymphocyte chemotactic activity. CCR1 ligand substrates of CD26 either lose (CCL5) or gain monocyte chemotactic activity (CCL3L1), but also gain lymphocyte chemotactic activity (CCL3L1 and CCL5). On this basis, a pro-inflammatory action of CD26 in RA can be proposed. It is therefore not possible to speculate whether the beneficial effect of CD26 blockers in diabetic patients in terms of incidence of RA relates to its chemokine-processing capacity. We have to await a more detailed molecular characterization of the chemokine substrates of CD26 present in synovial fluid allowing to discriminate between intact and post-translationally modified chemokine isoforms.

Table 1: Human chemokines as DPP IV substrates potentially present in RA synovium

\begin{tabular}{|c|c|c|c|c|}
\hline Chemokine & Isoform & Receptor & Chemotaxis & Reference \\
\hline CXCL9 & CXCL9(3-103) & CXCR3 & Reduction & [52] \\
\hline CXCL10 & CXCL10(3-77) & CXCR3 & Reduction & {$[52]$} \\
\hline CXCL11 & CXCL11(3-73) & CXCR3 & Reduction & {$[52]$} \\
\hline CXCL12 & CXCL12(3-67) & $\begin{array}{l}\text { CXCR4 } \\
\text { ACKR3 }\end{array}$ & $\begin{array}{l}\text { Reduction } \\
\text { Reduction }\end{array}$ & {$[48,53,54]$} \\
\hline CCL3L1 & CCL3L1(3-70) & $\begin{array}{l}\text { CCR1 } \\
\text { CCR3 } \\
\text { CCR5 }\end{array}$ & $\begin{array}{l}\text { Potentiation } \\
\text { Reduction } \\
\text { Potentiation }\end{array}$ & {$[55-56]$} \\
\hline CCL4 & CCL4(3-69) & $\begin{array}{l}\text { CCR1 } \\
\text { CCR2 } \\
\text { CCR5 } \\
\end{array}$ & $\begin{array}{l}\text { Potentiation } \\
\text { Potentiation } \\
\text { Unchanged }\end{array}$ & [57] \\
\hline CCL5 & CCL5(3-68) & $\begin{array}{l}\text { CCR1 } \\
\text { CCR3 } \\
\text { CCR5 } \\
\end{array}$ & $\begin{array}{l}\text { Reduction } \\
\text { Reduction } \\
\text { Potentiation }\end{array}$ & [58-59] \\
\hline CCL14(9-74) & CCL14(11-74) & $\begin{array}{l}\text { CCR1 } \\
\text { CCR3 } \\
\text { CCR5 }\end{array}$ & $\begin{array}{l}\text { Reduction } \\
\text { Reduction } \\
\text { Reduction }\end{array}$ & [60] \\
\hline
\end{tabular}




\subsection{Matrix metalloproteinases (MMPs)}

Matrix metalloproteinases (MMPs) are a family of $\mathrm{Zn}^{2+}$-dependent endoproteinases with 23 members in the human species. They were discovered as proteolytic enzymes that degrade the extracellular matrix (ECM), hence their name. MMPs have an important role in physiological processes that implicate matrix remodeling, including embryo implantation and development, bone morphogenesis, blood vessel remodeling, menstrual cycle, cell death, necrosis and immune cell migration. Consequently, altered expression and/or deregulation of MMP activities in vivo has been related with the development of many pathologies, including acute and chronic inflammatory diseases, autoimmune diseases and cancer. Therefore, upregulation of MMPs is directly correlated with disease development in, for instance, cardiovascular diseases, RA, neurological disorders and cancer. Such disease associations stimulated a considerable interest in MMP inhibitors as therapeutic treatments [61].

In all the named physiological and pathological processes, the conventional dogma was that MMPs mainly participated in degrading the ECM. However, this misinterpretation was rectified by the disappointing results of several clinical trials in which MMP inhibitors were used as a treatment of cancer [62]. The possibility that some of the MMP functions may be beneficial for the host, whereas MMP inhibitors may be detrimental was indeed missed in the early studies and, therefore, the involved MMPs may not always constitute therapeutic targets [63].

More recently, many novel MMP substrates were determined, including membrane proteins, soluble factors, such as cytokines and chemokines, and surprisingly many intracellular proteins (reviewed in [64-68]). Some of these substrates are proteins implicated in autoimmune diseases, such as myelin basic protein (MBP) in MS and many intracellular substrates in SLE [69]. Finally, several research groups proved that MMPs might act as signaling molecules and transcription factors [70, 71]. Together, these data prove that the roles of MMPs in disease development are more complex than originally thought.

\subsubsection{MMPs AND CHEMOKINES}

The cleavage of chemokines can induce potentiation or inactivation of their activity. Interestingly, MMPs are also able to convert chemokine agonists into antagonists. Table 2 summarizes the complex biological regulation of chemokines by MMPs.

Neutrophils are mainly regulated by CXC chemokines such us CXCL8 (in humans) and CXCL6 (in mice), which both signal through the receptors CXCR2 and CXCR1 [72-73]. For these chemokines, processing by MMPs plays a positive role in the regulation of neutrophil infiltration. MMP-8 and MMP-9, the two MMPs present in neutrophils are able to increase or potentiate human CXCL8 activity and mouse CXCL6 after cleavage [74-76]. This effect was later also described for MMP-13 and MMP-14 acting on human CXCL8 [74-77]. Thus, intracellular calcium influx and chemotaxis by CXCL8 were highly upregulated after cleavage by MMP-8, MMP-9, MMP-13 and MMP-14. Similar findings were observed for human CXCL5 of which the chemotactic function was enhanced after processing by MMP-1 and MMP-8 [74]. Interestingly, an increase of 3-8 fold on CXCL5 activity takes place in vitro after initial cleavage by MMP-9, but longer incubation leads to complete degradation of the molecule [74]. This increase in activity is even more striking in vivo. Indeed, intact human CXCL5, intraperitoneally injected at $300 \mathrm{pmol}$ in mice, fails to attract neutrophils whereas injection with 100 pmol CXCL5(8-78) and 30 pmol CXCL5(9-78) already results in significant neutrophil accumulation in the peritoneal cavity of mice [78]. 
The majority of $\mathrm{CXCL}$ chemokine family members are inactivated by MMP-12 [79]. CXCL1, CXCL2, CXCL3, CXCL5, CXCL6 and CXCL8 are cleaved by MMP-12, with deletion of the specific Glu-Leu-Arg (ELR) receptor-binding motif. In addition, other MMPs are able to inactivate other CXC chemokines. For instance, MMP-9 processes CXCL1, CXCL4 and CXCL7 [75,76] and MMP-8 and MMP-9 cleave the C-terminal part of CXCL9 and CXCL10, inactivating these chemokines [76]. CXCL11 is inactivated by MMP-9 and is completely degraded by MMP-7. CXCL9 and CXCL10 were described as substrates of MMP-7, MMP-8, MMP-9, and MMP-12 [76-80] but the context in which such cleavages occur may yield different outcomes and are not always confirmed. CXCL12 is inactivated by MMP-2 and the resulting fragments are neurotoxic [81].

MMPs mostly affect the recruitment of macrophages/monocytes by CC chemokines in a negative way. CCL7 is cleaved by MMP-2 generating an inactive but antagonistic molecule that still interacts with the receptors CCR1, CCR2 and CCR3, hence blocking the intact CCL7 to bind to these receptors and to generate its inflammatory effect [82]. Similar consequences occur to other members of the CC chemokine family, e.g. CCL2, CCL8 and CCL13. These chemokines are processed by several MMPs and are converted into antagonists $[79,82,83]$. Another antagonist originated after chemokine cleavage by MMPs, in particular MMP-2, is CX3CL1 [84].

C-terminal processing of chemokines by MMPs mainly affects their capacity to bind to GAGs. This is the case for CXCL11, which is cleaved at its C-terminal helix by MMP-8 and MMP-11 [85]. In addition, it is noteworthy to mention that MMPs are capable to process GAGs. For instance, MMP-9, MMP-14, and MMP-16 shed syndecan-4 and MMP-9 induces release of syndecan-1 [86-87].

\subsubsection{MMPS, CHEMOKINES AND AUTOIMMUNITY}

Inflammation occurs in many pathologies, as in wound healing after injury or in response to an infection. In all these process, leukocytes are attracted by chemokines to the site of inflammation. As described above in detail, MMPs are able to process and change chemokine properties, influencing the outcome of the inflammatory response. As a consequence, MMPs steer chemokines as key molecules to drive many autoimmune diseases. Therefore, MMPs were suggested as possible therapeutic targets, but it is essential to take into account the complete cytokine-MMP-chemokine network as the real axis regulating leukocyte infiltration. This issue was well studied in an experimental autoimmune encephalomyelitis (EAE) model of MS [88]. The authors show that MMP-2 and MMP-9 are essential for the penetration of leukocytes through the parenchymal basement membrane of the blood-brain barrier. They demonstrate that the balance between TNF- $\alpha$ versus interferon (IFN)- $\gamma$ regulates mainly MMP-9 secretion and activation of astrocytes. In turn, this regulates the levels and activity of chemokines that attract $T$ cells into the central nervous system to induce EAE symptoms. In the case of MMP-2 and MMP-9 in EAE, both gelatinases induce early leukocyte migration by selective cleavage of chemokines, which become more active, and the MMPs also trigger chemokine secretion by astrocytes via activation of the AKT/NF-KB-signaling pathway in a Notch-1-dependent manner [89-90].

Thus, the role of the MMPs in the regulation of chemokines and, as a consequence, of leukocyte infiltration into the central nervous system (CNS) is complex and still not well understood. One example is the role of the gelatinases in the modulation of CXCL12 and CXCL10 in EAE.

Active/uncleaved CXCL12 is present in the cuffs of post-capillary venules retaining leukocytes [91]. MMP-2 and MMP-9 may inactivate this chemokine, allowing leukocytes to respond to other chemokines such as CXCL10 localized outside the cuff. Moreover, although MMP-9 can inactivate CXCL10, its local production can be strongly upregulated generating a chemotactic effect. Another 
abundant chemokine in the inflamed CNS is CCL2, which is a substrate of many MMPs and which is processed into an antagonist $[77,84,92]$ (Table 2 ).

Table 2: Processing of human chemokines by MMPs.

\begin{tabular}{|c|c|c|c|c|c|}
\hline Chemokine & MMP & Created Isoform & Receptor & Effect & References \\
\hline CXCL1 (1-72) & \begin{tabular}{|l|} 
MMP-9, \\
MMP-12 \\
\end{tabular} & \begin{tabular}{|l} 
Degraded \\
$(7-72)$
\end{tabular} & CXCR2 & Inactivation & {$[75,76,79]$} \\
\hline CXCL2 (1-73) & $\begin{array}{l}\text { MMP-12, -9, -1 } \\
\text { MMP-12 } \\
\end{array}$ & \begin{tabular}{|l}
$(5-73)$ \\
$(7-73)$ \\
\end{tabular} & CXCR2 & Inactivation & [79] \\
\hline CXCL3 (1-73) & MMP-12 & $(7-73)$ & CXCR2 & Inactivation & {$[79]$} \\
\hline CXCL4 (1-85) & MMP-9 & Degraded & CXCR3 & Inactivation & {$[75]$} \\
\hline \multirow[t]{2}{*}{ CXCL5 (1-78) } & $\begin{array}{l}\text { MMP-1, }-9,-12 \\
\text { MMP-9 } \\
\text { MMP-1, }-8,-9 \\
\end{array}$ & $\begin{array}{l}(6-78) \\
(7-78) \\
(8-78) \\
\end{array}$ & \multirow[t]{2}{*}{ CXCR2 } & Potentiation & {$[74,76,79]$} \\
\hline & MMP-12 & $(11-78)$ & & Inactivation & {$[76,79]$} \\
\hline \multirow{2}{*}{ CXCL6 (1-77) } & \begin{tabular}{|l|} 
MMP-8, -9 \\
MMP-9 \\
\end{tabular} & $\begin{array}{l}(6-77),(7-77) \\
(7-77)\end{array}$ & CXCR1,CXCR2 & No change & {$[74,76]$} \\
\hline & \begin{tabular}{|l} 
MMP-12 \\
MMP-1, -9 \\
\end{tabular} & $\begin{array}{l}(15-77) \\
\text { Degraded } \\
\end{array}$ & CXCR1,CXCR2 & Inactivation & {$[79]$} \\
\hline CXCL7 (1-77) & \begin{tabular}{|l|} 
MMP-9, \\
MMP -12 \\
\end{tabular} & $\begin{array}{l}\text { Not defined } \\
(1-57)\end{array}$ & CXCR2 & Inactivation & [75-79] \\
\hline \multirow[t]{2}{*}{ CXCL8 (1-77) } & $\begin{array}{l}\text { MMP-1, -8, -9, - } \\
12,13,-14 \\
\end{array}$ & $(7-77)$ & \multirow[t]{2}{*}{ CXCR1, CXCR2 } & Potentiation & {$[74,75,77,78,79]$} \\
\hline & MMP-12 & $(10-77)$ & & Inactivation & {$[79]$} \\
\hline CXCL9 (1-103) & \begin{tabular}{|l|} 
MMP-7, -8, -9, - \\
12 \\
\end{tabular} & (1-94), (1-93) & CXCR3 & Inactivation & {$[76,80]$} \\
\hline CXCL10 (1-77) & $\begin{array}{l}\text { MMP-7, -8, -9, - } \\
12 \\
\end{array}$ & $(1-71)(1-73)$ & CXCR3 & Inactivation & {$[76,80]$} \\
\hline \multirow[t]{2}{*}{ CXCL11 (1-73) } & $\begin{array}{l}\text { MMP-7 } \\
\text { MMP-9 } \\
\text { MMP-12 } \\
\text { MMP-8 } \\
\end{array}$ & $\begin{array}{l}\text { (1-58), degraded } \\
(1-58),(5-58) \\
(1-58),(5-58), \text { degraded } \\
(5-63),(5-58)\end{array}$ & \multirow[t]{2}{*}{ CXCR3,CXCR7 } & Inactivation & {$[80]$} \\
\hline & MMP-8, -12 & $(5-73)$ & & Antagonist & {$[80]$} \\
\hline CXCL12 (1-68) & \begin{tabular}{|l|} 
MMP-1, -2, -3, - \\
$9,-13,-14$ \\
\end{tabular} & $(5-67)$ & CXCR4, CXCR7 & Inactivation & {$[79,81]$} \\
\hline $\mathrm{CX}_{3} \mathrm{CL} 1(1-76)$ & MMP-2 & $(5-71)$ & CX3CR1 & Antagonist & [84] \\
\hline CCL2 (1-76) & $\begin{array}{l}\text { MMP-1, -3, -8, - } \\
12 \\
\end{array}$ & $(5-76)$ & CCR2 & Antagonist & {$[79,82,83]$} \\
\hline CCL7 (1-76) & $\begin{array}{l}\text { MMP-1, -2, -3, - } \\
12,-13,-14 \\
\end{array}$ & $(5-76)$ & CCR1, CCR2 & Antagonist & {$[79,82,83]$} \\
\hline CCL8 (1-76) & MMP-1, $-3,-12$ & $(1-73),(5-73)$ & CCR-2, CCR5 & Antagonist & {$[79,82]$} \\
\hline CCL13 (1-75) & MMP-1, -12 & $(5-72)$ & CCR3, CCR5 & Antagonist & {$[79,84]$} \\
\hline
\end{tabular}


One of the most complex and heterogeneous autoimmune diseases is SLE. The underlying pathogenesis involves hyperactive B and T cells, an increase of cell apoptosis and a defect in apoptotic cell clearance. These mechanisms trigger adaptive immune reactivity against ubiquitous intracellular proteins, acting as autoantigens. The production of high levels of non-organ-specific, self-reactive autoantibodies against many intracellular components such as DNA, RNA, p53, actins, tubulins and histones is a hallmark of SLE. The interactions between autoantigens and autoantibodies lead to the formation and deposition of immune complexes (IC) in different organs that induce local activation of the complement system and tissue injury. The role of MMPs is essential because some of the autoantigens, such as actins and tubulins, have been shown to be MMP substrates $[69,93]$.

Many chemokines are upregulated in SLE. CCL2 levels in serum of SLE patients increase with the progression of disease activity [94] and the levels of this chemokine in the cerebral spinal fluids of patients with neuropsychiatric SLE syndromes are highly increased [95]. CCL5 is also upregulated in SLE serum samples and correlates with disease activity [96]. Additionally CCL2 and CCL5 are detectable in kidney tissues and in urine of patients with lupus nephritis [97] and in the SLE mouse model fas-knockout (lymphoproliferative or LPR mice) [98]. CCL2 can be cleaved by many MMPs diminishing its chemoattractant activity and creating an antagonist (see above). CXCL10 and CXCL9 have chemotactic activity for Th1 cells, which express their inducer IFN- $\gamma$ [99-101]. Th1 cells and IFN$\gamma$ are important for the development of SLE. Consequently, these chemokines, elevated in active SLE, may be implicated in the progression of the disease. In addition, CXCL8 and CXCL1 are elevated in SLE and their levels correlate with the disease activity [101].

The extensive spectrum of chemokines that is expressed simultaneously in autoimmune diseases and the different effects of MMPs on various chemokines suggest that some of these interactions co-determine disease activity. This element highlights how important it is to study posttranslational modifications of chemokines within the complex regulation of the cytokine-MMP-chemokine interactions in autoimmune diseases.

\section{Glycosylation}

\subsection{Introduction}

Glycosylation is one of the most complex and heterogeneous posttranslational modifications of proteins. N-linked sugars are co-translationally attached to the sequons Asn/Xaa/Ser or Asn/Xaa/Thr (Xaa is any amino acid except Pro) on nascent unfolded proteins and, in fact, contribute to proteinfolding [102]. In the human and mouse species, N-linked sugars are often rather large and branched structures and may occupy an equivalent space volume of about a single protein domain of 100 amino acids. Because this is the approximate size of most chemokines, it is clear that this modification may have a considerable impact on chemokine biology (vide infra for examples). Another common form of glycosylation is on serines (Ser) or threonines (Thr). On a theoretical basis this O-linked glycosylation occurs more frequently and is usually linear and shorter and is reflected by small mass differences between the O-glycosylated and the aglycosyl forms of the chemokines. Special types of O-glycosylation, including single O-fucose, O-GlcNACylation and O-linked structures on modified Pro (OH-Pro) or Lys (OH-Lys) [103] have not yet been described for any chemokine. 


\subsection{Functions of chemokine glycosylation}

Structural data are basic elements in the understanding of chemokine biology. However, it is also important to know the main functions of oligosaccharides. An important function is protection against proteases: sugars act as shields for the underlying protein domains and absence of glycosylation thus makes a protein more vulnerable for proteolysis, as has been first clearly demonstrated for the one-domain enzyme ribonuclease [104-105]. A second critical function is the possibility of sugars to bind to lectins and vice-versa. This implies that glycosylated chemokines may be concentrated at sites of their cognate lectin positions or, alternatively, if chemokines can bind sugars, they may act as lectins. For instance, in the immune system the sialyl-Lewis $\mathrm{X}$ structure will bind to the various selectins on endothelia, leukocytes or platelets [103]. Here it is already relevant to add that many chemokines have positively charged Arg or Lys residues in their C-terminal region that may bind to the repetitive negative charges of sulphated glycans and amino acids of GAGs [106]. A third function of oligosaccharides is related to receptor interactions. As has been described for other cytokines such as interleukin-1 [107], the presence of a large N-linked sugar on a chemokine may diminish the close interaction between ligand and receptor and following signal induction [108]. Translated to concentrations, this implies that large oligosaccharides may lower the specific activity of cytokines, chemokines and many other glycoproteins [107-108]. A fourth element in glycobiology is cell-specific glycosylation of proteins, including chemokines and chemokine receptors. In view of the above elements, this implies that cell- and tissue-specific interactions are possible between chemokines and chemokine receptors and such interactions may determine the localization of the chemotactic event.

\subsection{Most chemokines have no $\mathrm{N}$-linked and few have $\mathrm{O}$-linked glycosylation}

In Supplementary Table 1 an overview is provided of chemokine glycosylation, as generated by the bio-informatics tools NetNGlyc and NetOGlyc. This analysis and comparison of human and mouse $\mathrm{CCL}$ and $\mathrm{CXCL}$ reveals - in contrast with the common perception of glycosylated chemokines - that chemokine glycosylation is more exception than rule [108]. The essence of these analyses is provided in Table 3 and yields the insight that most human and mouse CXCL do not contain theoretical $\mathrm{N}$-linked glycosylation sites. Experimental evidence for glycosylation does not exist for any of the human or mouse CXC chemokines. Human and mouse CC chemokines may be glycosylated. Up to $50 \%$ possess, on a theoretical basis, $\mathrm{N}$-linked sequons, of which occupancies have been validated in single members. O-linked glycosylation has been validated in $12 \%$ of the human $\mathrm{CCL}$ and in $9 \%$ of the mouse CCL. Altogether, this information implies that probably all human and mouse $\mathrm{CXCL}$ and also the majority of human and mouse $\mathrm{CCL}$ remain unprotected against proteases and are therefore rapidly turned over in protease-laden environments of inflammations and infections.

For those chemokines that contain $\mathrm{N}$ - or O-linked attachment sites on a theoretical basis, the presence of sugars needs to be validated with experimental evidence. Both human and mouse CCL1 contain an $\mathrm{N}$-linked sugar and the first $\mathrm{N}$-acetylglucosamine (GICNAc) of the oligosaccharide attached to the Asn was well resolved in crystallography analysis [109]. In Ser-CCL1, the N linked structure is disordered and only the GIcNAc of the attached N-linked oligosaccharide is well resolved in the electron density map, attesting to its high flexibility. No major structural change is imposed by the $\mathrm{N}$ Linked sugar [109]. 
Human and mouse CX3CL1 are exceptional chemokines because these are at least three to four times larger in length than the average CC and CXC chemokines (see supplementary Table 1). CX3CL1 contains both $\mathrm{O}$ - and $\mathrm{N}$-linked sugars. The $\mathrm{N}$-linked sugar results in apical expression of this chemokine in renal tubular cells where it exerts both leukocyte chemotactic and adhesion functions [110].

Natural murine CCL2 from virally infected fibroblasts is smaller than human CCL2 and possesses a molecular mass that is also smaller than that expected from the predicted cDNA-derived sequence [111]. Recombinant CDNA-derived mouse CCL2, expressed in CHO cells, is heavily glycosylated at the $\mathrm{C}$-terminus with mainly O-linked (and a minor quantity of $\mathrm{N}$-linked) sugars. These structures are not necessary for eliciting chemotaxis [112]. Human CCL2 from MG 63 osteosarcoma cells contains sialylated structures [113]. For functional studies, human CCL2 CDNA was expressed in bacteria and the yeast Pichia pastoris and it was observed that the glycosylated forms had a lower specific activity, but a longer half-life, than the aglycosyl forms [114], in line with observations made with other glycoproteins [104,107-108].

Finally, the unique member of the C-chemokines, XCL1, with GalNAc sugar units in its mucin domain was chemically synthesized. The preparation of such glycovariants and of synthetic aglycosyl forms will in the future enable to perform comparisons of unglycosylated versus glycosylated chemokines to better understand the biological functions of oligosaccharides attached to chemokines in vitro and in vivo [115].

\subsection{Most chemokines have GAG-binding lectin-like properties}

The glycobiology of most chemokines does not end with the absence of oligosaccharides and with a few examples of experimentally proven glycosylated chemokines. Indeed, most chemokines have a C-terminal alpha-helical domain in which repetitive positively charged residues (Arg and Lys) strongly interact with the negatively charged sulphates of GAGs in the extracellular matrix. In other words, all chemokines have GAG-binding lectin-like properties. This is illustrated in Figure 1 with the example of human CCL8, which is a CC chemokine with an exact definition of the crystal structure [116] and with the example of CXCL8 [117-118]. However, amino acids involved in GAG binding are not restricted to the C-terminal domain. Chemokine - GAG interactions are essential for presentation of chemokines on endothelial surfaces, retention of chemokines in tissues and in vivo chemokine activity [119-123]. In addition, GAG binding domains on chemokines are implicated in the generation of cooperative or synergistic activity between chemokines as exemplified for CCL21 and CXCL12 [124]. GAGs affect chemokine oligomerization and vice versa [125]. Recognized GAG binding motifs include $X B B B X X B X$ and $X B B X B X$ sequences with $B$ representing a basic amino acid and $X$ any amino acid. A few chemokines, i.e. human CCL21, CXCL9 and CXCL12 $\gamma$, possess an additional C-terminal extension of about 30 amino acids with multiple positively charged amino acids and GAG-binding domains. These $\mathrm{C}$-terminal tails have a very high affinity for GAGs and have profound effects on the activity of these chemokines as shown for CCL21 and CXCL12 $\gamma$ [126-128]. Moreover, peptides corresponding to the C-terminal domain of these "elongated" chemokines inhibit GAG binding of other chemokines and reduce inflammation in animal models [128-130].

\subsection{Glycosylation of chemokine receptors}

The glycosylation of chemokine receptors has not yet been sufficiently studied. We introduced the human and mouse chemokine receptor files into the NetNGlyc and NetOGlyc programs to find out that most receptors contain glycosylation sites. Therefore, we postulated that, in contrast with the vulnerable chemokine ligands, most of the chemokine GPCRs are protected for a longer life by 
attached oligosaccharides. From the literature, a number of examples can be mentioned in which the glycosylation of receptors was validated. CXCR4 has an $\mathrm{N}$-linked site at the $\mathrm{N}$-terminus. The occupied form hinders the binding of HIV strains via gp120 [131]. In addition, sulfation of tyrosines (Tyr) in the N-terminal region of CXCR4 clearly improves interaction with CXCL12 ligands [132]. In addition, CXCL12 $\gamma$, a form of CXCL12 generated through alternative splicing, binds this sulfo-Tyr through its highly positively charged C-terminal tail. Although the CXCL12 $\gamma$ isoform bound more strongly to sulfated CXCR4, it did not induce in vitro signaling or chemotactic activity [127]. CXCR2 has two $\mathrm{N}$-linked complex oligosaccharides that protect the receptor from proteolytic attack by serine proteases. However, these sugars do not influence the signaling of chemotactic activity of the CXCR2 ligands [133]. CCR5 has an O-linked sialylated sugar at the $\mathrm{N}$-terminus (residue 6) and sulfated Tyr that are suggested to contribute to chemokine binding, as described above for GAGs, and maybe enhancing chemotaxis by ligands [134].

Table 3 Theoretical and experimentally validated chemokine glycosylation

\begin{tabular}{|l|l|l|l|l|}
\hline Chemokines & $\mathrm{Nr}$ & $\begin{array}{l}\text { Theoretical } \\
\text { N-linked site (\%) }\end{array}$ & $\begin{array}{l}\text { Validated } \\
\text { N-linked sugars (\%) }\end{array}$ & $\begin{array}{l}\text { Validated } \\
\text { O-linked sugars (\%) }\end{array}$ \\
\hline Human CCL & 26 & $10(38 \%)$ & $1(4 \%)$ & $3(12 \%)$ \\
\hline Mouse CCL & 23 & $11(48 \%)$ & $1(4 \%)$ & $2(9 \%)$ \\
\hline Human CXCL & 17 & $3(18 \%)$ & $0(0 \%)$ & $0(0 \%)$ \\
\hline Mouse CXCL & 15 & $3(20 \%)$ & $0(0 \%)$ & $0(0 \%)$ \\
\hline
\end{tabular}

Human and mouse $\mathrm{CCL}$ and $\mathrm{CXCL}$ chemokines were analyzed for the presence of theoretical $\mathrm{N}$-linked and O-linked oligosaccharide attachment sites (see Supplementary Table 1). For each chemokine subfamily, the number $(\mathrm{Nr})$ of analyzed chemokines, the number with theoretical $\mathrm{N}$-linked sequons and the number of chemokines with experimentally validated of $\mathrm{N}$ - or O-linked sugars are provided. 


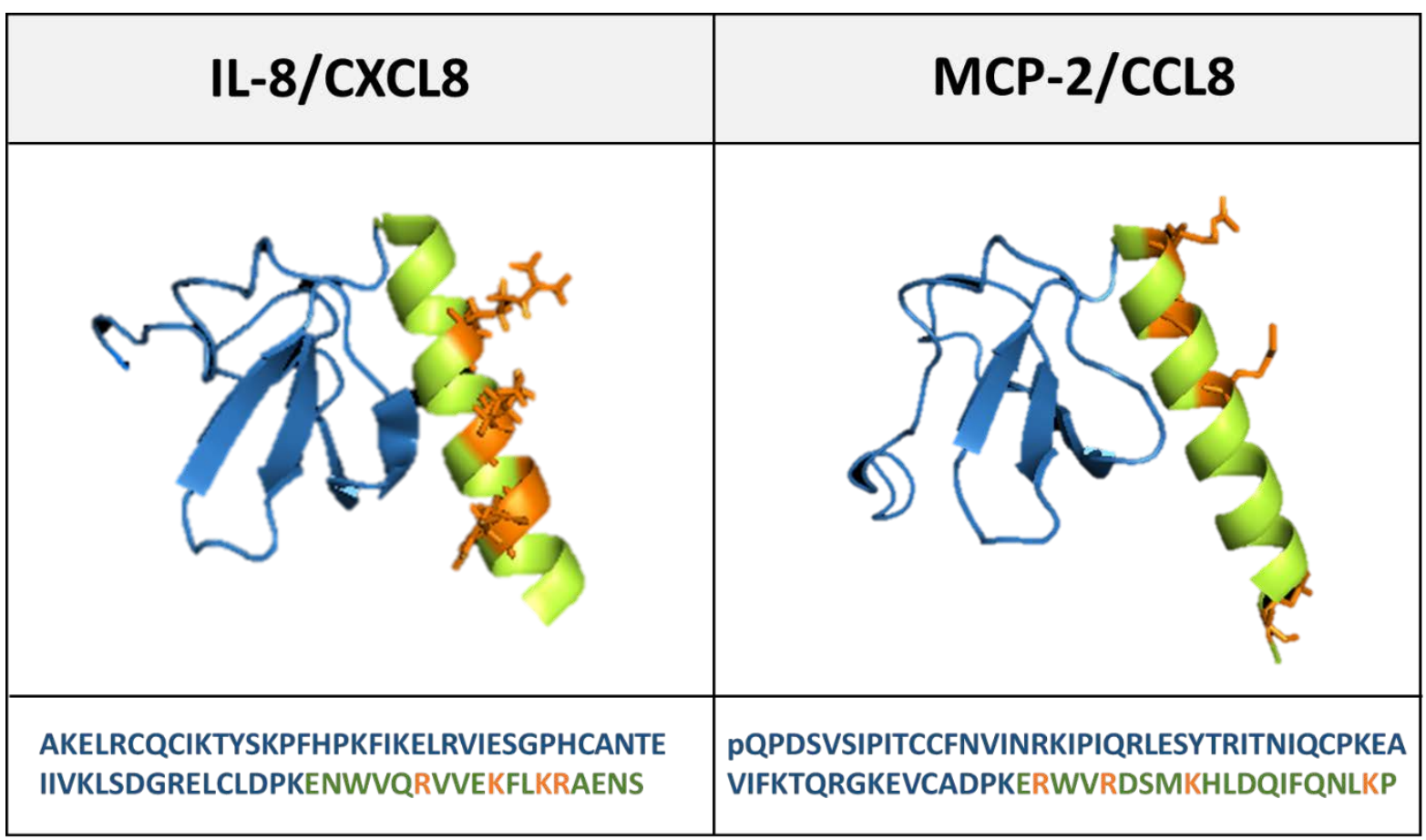

Figure 1. Human CCL8 and human CXCL8 structures

The coordinates of the structures of human CXCL8 [117-118] and human CCL8 [116] were used to generate molecular models (top) of the primary sequences provided in one-letter code for amino acids (bottom). The $\mathrm{N}$-terminal parts interacting with the chemokine receptors are indicated in blue, whereas the $\mathrm{C}$-terminal $\alpha$-helical parts in green interact with GAGs. The positively charged Lys (K) and $\operatorname{Arg}(R)$ residues are indicated in orange and these amino acids contribute to the high pl values of chemokines and, by their charges, electrostatically interact with the negatively charged sulfate groups of GAGs. 


\section{Other posttranslational modifications}

\subsection{Conversion of the $\mathrm{N}$-terminal glutamine to pyroglutamic acid}

A characteristic of most monocyte chemotactic proteins (MCPs) including human CCL2, CCL7, CCL8 and CCL13, is the presence of a Gln as first residue after removal of the signal peptide [135-141]. As in hormones with an N-terminal Gln, in MCPs this amino acid is converted in pyroglutamic acid either spontaneously through the removal of ammonia or through the action of glutamyl cyclases $Q C$ or isoQC. Studies with QC and isoQC knock-out mice rather point towards isoQC as the enzyme responsible for ring closure in chemokines and QC for modification of peptide hormones such as the thyrotropin-releasing hormone [142-143]. The ring closure of the N-terminus not only protects MCPs from proteolysis by a number of aminopeptidases but is also important for its biological activity. Indeed, it was shown that recombinant CCL8 with an N-terminal Gln was less potent than the natural CCL8 form containing a pyroglutamic acid [144]. In addition, use of a QC inhibitor or small interfering RNA confirmed the importance of the cyclization of the N-terminal Gln [145]. The N-terminal pyroglutamic acid of CCL8 was shown to be buried in the chemokine dimer providing additional protection of the $\mathrm{N}$-terminal region against proteolytic degradation [116].

\subsection{Chemokine citrullination}

In addition to glycosylation and the formation of an $\mathrm{N}$-terminal pyroglutamic acid, also side chain modifications may modify the sensitivity of chemokines to proteolytic cleavage. The serine protease thrombin is very efficient in cleaving the major human neutrophil attractant CXCL8 after the most $\mathrm{N}$ terminal Arg into the more potent CXCL8(6-77), a major CXCL8 form produced by leukocytes [146147]. This Arg, in contrast to all other arginines in CXCL8, is efficiently modified into citrulline (Cit) by peptidylarginine deiminases (PADs) [148]. Cit and Arg differ only one mass unit but in contrast to $\mathrm{Arg}$, Cit is a neutral amino acid. Citrullination of CXCL8 at Arg 5 results in full protection against proteolytic activation of CXCL8 by thrombin. In addition, it prevents cleavage at this position by plasmin, which also cleaves proteins after positively charged amino acids. Although differences between intact CXCL8 and its citrullinated form are minor or insignificant in terms of CXCR1 and CXCR2 interactions and in vitro activity, citrullinated CXCL8 has a reduced affinity for GAGs and the Duffy antigen/receptor for chemokines (DARC) or ACKR1 and fails to recruit neutrophils upon intraperitoneal injection in mice [149]. In contrast, citrullinated CXCL8 upregulates CD11b expression on neutrophils is more potent in shedding L-selectin (CD62L) and in mobilizing neutrophils to the blood upon intravenous injection in rabbits [149].

In addition to CXCL8, CXCL5 and CXCL10 have also been identified as natural citrullinated chemokines [150-151]. Citrullination of CXCL10 is also highly site-specific in that only the most $\mathrm{N}$ terminal Arg is modified by PADs. Citrullination reduces the signaling and chemotactic activity of CXCL10. Although only the most N-terminal Arg, and not the Glu-Leu-Arg-motif, is modified upon incubation with PAD (without cleavage of the disulfide bridges), citrullinated CXCL5 shows reduced signaling properties on neutrophils through CXCR2 [76]. In addition, it fails to recruit neutrophils upon intraperitoneal injection in mice. Surprisingly, citrullinated CXCL5 becomes chemotactic for monocytes breaking the general dogma that Glu-Leu-Arg positive CXC chemokines are selective neutrophil attractants [151]. Incubation of other chemokines such as CXCL11 and CXCL12 with PADs also provokes citrullination leading to reduced chemotactic activity for lymphocytes $[150,152]$.

\subsection{Role of PADs and citrullinated chemokines in RA and MS}

A crucial role for citrullination of proteins was evidenced in RA and MS. In RA citrullinated proteins are typically the target for autoantibodies [153]. In fact, ACPA are major clinical markers currently in 
use for the diagnosis of RA and ACPA are present very early in the disease and even before disease onset [154]. Although high concentrations of inflammatory chemokines have been detected in synovial fluids of RA patients, limited information is available on the occurrence of citrullinated chemokines. A major problem is the difficulty to discriminate citrullinated from non-citrullinated chemokines with immunoassays. Yoshida et al. chemically cross-linked chemokines to antibodies against specific chemokines with glutaraldehyde, subsequently chemically modified citrullines with diacetylmonoxime and antipyrine and used antibodies against the chemically modified citrullines for detection [151]. As such, they could detect citrullinated CCL2, CCL3 and CXCL5 in sera and synovial fluid of patients. Surprisingly 10 -fold lower concentrations of citrullinated CCL2 were detected in synovial fluid versus sera. It is not clear whether chemokines are citrullinated intracellularly or extracellularly. Although most PAD activity is found in the cytoplasm, also extracellular PAD was reported in the synovial tissue of RA patients [155]. Moreover, PAD4, but not PAD2, is important for the formation of neutrophil extracellular traps (NETs) and formation of NETs has been connected to RA [156-158]. It is not clear whether citrullination of chemokines also generates autoantibodies in RA or whether chemokine citrullination is a mechanism to dampen the inflammation in the synovium.

In MS, citrullination is linked to modification of myelin basic protein (MBP) and glial fibrillary acidic protein (GFAP) and histones [159-162]. Although MBP is citrullinated also in healthy persons, the number of citrullines on MBP in white matter from established chronic MS patients is considerably higher [159]. In addition, in acute fulminating MS highly citrullinated MBP molecules make-up $90 \%$ of total MBP [160]. Both PAD2 and PAD4 enzymes are enhanced in MS patients [162-164]. Moreover, inhibitors of PAD4 reduce EAE induced with myelin oligodendrocyte glycoprotein derived peptide 35-55 [165]. So far, no evidence for the presence of ACPA or citrullinated chemokines has been reported in MS.

\subsection{Chemokine nitration}

A recently identified posttranslational modification on chemokines is nitration of the side chain of Tyr residues. Two chemokines, CCL2 and CXCL12 have been isolated as nitrated proteins.

Peroxynitrite is known to nitrate Tyr residues in proteins and is generated during inflammation and in tumors. Peroxynitrate-treated CCL2 has reduced chemotactic activity and nitration of CCL2 is reported during ischemia reperfusion injury as well as on tissue sections from cancer patients suffering from colon carcinoma or prostate cancer [166-168]. Nitrated CCL2 shows reduced binding to GAGs and fails to recruit leukocytes upon intraperitoneal injection. CXCL12 produced by stromal cells cultured in inflammatory conditions is also nitrated at its most N-terminal Tyr [169]. Such nitrated CXCL12 has reduced signaling properties through CXCR4 and reduced in vitro and in vivo lymphocyte chemotactic properties. In summary, both citrullination and nitration of chemokines appear to reduce the inflammatory activity of chemokines through minor modification of the protein structure.

\section{Conclusions}

We here elaborated on posttranslational modifications of chemokines as the third dimension of heterogeneity and place these modifications in the clinical context of autoimmune diseases such as diabetes, MS, RA and SLE. Proteolysis of chemokines by CD26 and MMPs has been studied in detail. Glycosylation of CC and CXC chemokines occurs rarely and protects the molecules against proteases. Most chemokines bind to GAGs. Finally, the biological effects of $\mathrm{N}$-terminal pyroglutamate, of citrullination by PADs and chemokine nitration were discussed. 


\section{Acknowledgement:}

The authors and other members of our research team wish to thank "maestro" Alberto Mantovani for more than 3 decades of extremely friendly and fruitful scientific collaboration, leading to the characterization of the cytokines IL-1 (1987) and IL-6 (1989) and the chemokines MCP-1/CCL2 (1989), IL-8/CXCL8 (1990), MCP-2/CCL8 (1994), MCP-3/CCL7 (1994), MIP-1 $\alpha / C C L 3$ (1995), MDC/CCL22 (1998), PARC/CCL18 (2002),...with a total of more than 30 joint publications.

All this work could be realized together with the many excellent experts from his research group through joint EC grants.

\section{Funding:}

This work was supported by the Interuniversity Attraction Poles Programme initiated by the Belgian Science Policy Office (I.A.P. Project 7/40), the Fund for Scientific Research of Flanders and C1 funding of the KU Leuven. E. U.-B. holds a postdoctoral research fellowship of the Research Foundation of Flanders (FWO-Vlaanderen). 


\section{References}

[1] A.M. Lambeir, C. Durinx, S. Scharpé, I. De Meester, Dipeptidyl-peptidase IV from bench to bedside: an update on structural properties, functions, and clinical aspects of the enzyme DPP IV, Crit. Rev. Clin. Lab. Sci. 40 (2003) 209-294.

[2] A. Mortier, M. Gouwy, J. Van Damme, P. Proost, S. Struyf, CD26/dipeptidylpeptidase IVchemokine interactions: double-edged regulation of inflammation and tumor biology, J. Leukoc. Biol. 99 (2016) 955-969.

[3] H. O'Leary, X. Ou, H.E. Broxmeyer, The role of dipeptidyl peptidase 4 in hematopoiesis and transplantation, Curr. Opin. Hematol. 20 (2013) 314-319.

[4] I. De Meester, A.M. Lambeir, P. Proost, S. Scharpé, Dipeptidyl peptidase IV substrates. An update on in vitro peptide hydrolysis by human DPPIV, Adv Exp Med Biol, 524 (2003) 3-17.

[5] H.A. O'Leary, M. Capitano, S. Cooper, C. Mantel, H.S. Boswell, R. Kapur, B. Ramdas, R. Chan, L. Deng, C.K. Qu, H.E. Broxmeyer, DPP4 truncated GM-CSF and IL-3 manifest distinct receptor-binding and regulatory functions compared with their full-length forms, Leukemia (2017) In Press.

[6] A. Casrouge, J. Decalf, M. Ahloulay, C. Lababidi, H. Mansour, A. Vallet-Pichard, V. Mallet, E. Mottez, J. Mapes, A. Fontanet, S. Pol, M.L. Albert, Evidence for an antagonist form of the chemokine CXCL10 in patients chronically infected with HCV, J. Clin. Invest. 121 (2011) 308-317.

[7] M. Metzemaekers, J. Van Damme, A. Mortier, P. Proost, Regulation of Chemokine Activity - A Focus on the Role of Dipeptidyl Peptidase IV/CD26, Front. Immunol. 7 (2016) 483.

[8] S. Iwata, C. Morimoto, CD26/dipeptidyl peptidase IV in context. The different roles of a multifunctional ectoenzyme in malignant transformation, J. Exp. Med. 190 (1999) 301-306.

[9] K.W. Christopherson, S.E. Uralil, N.K. Porecha, R.C. Zabriskie, S.M. Kidd, S.M. Ramin, G-CSF- and GM-CSF-induced upregulation of CD26 peptidase downregulates the functional chemotactic response of CD34+CD38- human cord blood hematopoietic cells, Exp. Hematol. 34 (2006) 10601068.

[10] G. Vanham, L. Kestens, I. De Meester, J. Vingerhoets, G. Penne, G. Vanhoof G, S. Scharpé, H. Heyligen, E. Bosmans, J.L. Ceuppens, P. Gigase, Decreased expression of the memory marker CD26 on both CD4+ and CD8+ T lymphocytes of HIV-infected subjects, J. Acquir. Immune Defic. Syndr. 6 (1993) 749-757.

[11] D.A. Fox, R.E. Hussey, K.A. Fitzgerald, O. Acuto, C. Poole, L. Palley, J.F. Daley, S.F. Schlossman, E.L. Reinherz, Ta1, a novel 105 KD human T cell activation antigen defined by a monoclonal antibody, J. Immunol. 133 (1984) 1250-1256.

[12] I. De Meester, S. Korom, J. Van Damme, S. Scharpé, CD26, let it cut or cut it down, Immunol. Today 20 (1999) 367-375.

[13] D. Röhrborn, J. Eckel, H. Sell, Shedding of dipeptidyl peptidase 4 is mediated by metalloproteases and up-regulated by hypoxia in human adipocytes and smooth muscle cells, FEBS Lett. 588 (2014) 3870-3877.

[14] C. Morimoto, S.F. Schlossman, The structure and function of CD26 in the T-cell immune response, Immunol. Rev. 161 (1998) 55-70. 
[15] R. Gerli, C. Muscat, A. Bertotto, O. Bistoni, E. Agea, R. Tognellini et al. CD26 surface molecule involvement in T cell activation and lymphokine synthesis in rheumatoid and other inflammatory synovitis. Clin. Immunol. Immunopathol. 80 (1996) 31-37.

[16] C. Muscat, A. Bertotto, E. Agea, O. Bistoni, R. Ercolani, R. Tognellini, F. Spinozzi, M. Cesarotti, R. Gerli, Expression and functional role of $1 F 7$ (CD26) antigen on peripheral blood and synovial fluid T cells in rheumatoid arthritis patients, Clin. Exp. Immunol. 98 (1994) 252-256.

[17] A. Mizokami, K. Eguchi, A. Kawakami, H. Ida, Y. Kawabe, T. Tsukada, T. Aoyagi, K. Maeda, C. Morimoto, S. Nagataki, Increased population of high fluorescence 1F7 (CD26) antigen on T cells in synovial fluid of patients with rheumatoid arthritis, J. Rheumatol. 23 (1996) 2022-2026.

[18] C.F. Deacon, H.E. Lebovitz, Comparative review of dipeptidyl peptidase-4 inhibitors and sulphonylureas, Diabetes Obes. Metab. 18 (2016) 333-347.

[19] J. Zhong, A. Maiseyeu, S.N. Davis, S. Rajagopalan, DPP4 in cardiometabolic disease: recent insights from the laboratory and clinical trials of DPP4 inhibition, Circ. Res. 116 (2015) 1491-1504.

[20] L.L. Baggio, D.J. Drucker, Therapeutic approaches to preserve islet mass in type 2 diabetes, Annu. Rev. Med. 57 (2006) 265-281.

[21] O. Giampietro, C. Giampietro, L.D. Bartola, M.C. Masoni, E. Matteucci, Sitagliptin as add-on therapy in insulin deficiency: biomarkers of therapeutic efficacy respond differently in type 1 and type 2 diabetes, Drug Des. Devel. Ther. 7 (2013) 99-104.

[22] R. Barreira da Silva, M.E. Laird, N. Yatim, L. Fiette, M.A. Ingersoll, M.L. Albert, Dipeptidylpeptidase 4 inhibition enhances lymphocyte trafficking, improving both naturally occurring tumor immunity and immunotherapy, Nat. Immunol. 16 (2015) 850-858.

[23] S.C. Kim, S. Schneeweiss, R.J. Glynn, M. Doherty, A.B. Goldfine, D.H. Solomon, Dipeptidyl peptidase- 4 inhibitors in type 2 diabetes may reduce the risk of autoimmune diseases: a populationbased cohort study, Ann. Rheum. Dis. 74 (2015) 1968-1975.

[24] D.L. Asquith, S.A. Bryce, R.J. Nibbs, Targeting cell migration in rheumatoid arthritis, Curr. Opin. Rheumatol. 27 (2015) 204-211.

[25] F. Bachelerie, A. Ben-Baruch, A.M. Burkhardt, C. Combadière, J.M. Farber, G.J. Graham, R. Horuk, A.H. Sparre-Ulrich, M. Locati, A.D. Luster, A. Mantovani, K. Matsushima, P.M. Murphy, R. Nibbs, H. Nomiyama, C.A. Power, A.E. Proudfoot, M.M. Rosenkilde, A. Rot, S. Sozzani, M. Thelen, O. Yoshie, A. Zlotnik, International Union of Basic and Clinical Pharmacology. LXXXIX. Update on the extended family of chemokine receptors and introducing a new nomenclature for atypical chemokine receptors, Pharmacol. Rev. 66 (2014) 1-79.

[26] M. Rampart, A.G. Herman, B. Grillet, G. Opdenakker, J. Van Damme, Development and application of a radioimmunoassay for interleukin-8: detection of interleukin-8 in synovial fluids from patients with inflammatory joint disease, Lab. Invest. 66 (1992) 512-518.

[27] Z. Szekanecz, A.E. Koch, Successes and failures of chemokine-pathway targeting in rheumatoid arthritis, Nat. Rev. Rheumatol. 12 (2016) 5-13.

[28] D.A. Rao, M.F. Gurish, J.L. Marshall, K. Slowikowski, C.Y. Fonseka, Y. Liu, L.T. Donlin, L.A. Henderson, K. Wei, F. Mizoguchi, N.C. Teslovich, M.E. Weinblatt, E.M. Massarotti, J.S. Coblyn, S.M. Helfgott, Y.C. Lee, D.J. Todd, V.P. Bykerk, S.M. Goodman, A.B. Pernis, L.B. Ivashkiv, E.W. Karlson, P.A. 
Nigrovic, A. Filer, C.D. Buckley, J.A. Lederer, S. Raychaudhuri, M.B. Brenner, Pathologically expanded peripheral T helper cell subset drives B cells in rheumatoid arthritis, Nature 542 (2017) 110-114.

[29] P. Proost, S. Verpoest, K. Van de Borne, E. Schutyser, S. Struyf, W. Put, I. Ronsse, B. Grillet, G. Opdenakker, J. Van Damme, Synergistic induction of CXCL9 and CXCL11 by Toll-like receptor ligands and interferon-gamma in fibroblasts correlates with elevated levels of CXCR3 ligands in septic arthritis synovial fluids, J. Leukoc. Biol. 75 (2004) 777-784.

[30] P. Proost, A.K. Vynckier, F. Mahieu, W. Put, B. Grillet, S. Struyf, A. Wuyts, G. Opdenakker, J. Van Damme, Microbial Toll-like receptor ligands differentially regulate CXCL10/IP-10 expression in fibroblasts and mononuclear leukocytes in synergy with IFN-gamma and provide a mechanism for enhanced synovial chemokine levels in septic arthritis, Eur. J. Immunol. 33 (2003) 3146-3153.

[31] J.M. Pandya, A.C. Lundell, K. Andersson, I. Nordstrom, E. Theander, A. Rudin, Blood chemokine profile in untreated early rheumatoid arthritis: CXCL10 as a disease activity marker. Arthritis Res. Ther. 19 (2017) 20.

[32] G. Li, P. Cunin, D. Wu, D. Diogo, Y. Yang, Y. Okada, R.M. Plenge, P.A. Nigrovic, The Rheumatoid Arthritis Risk Variant CCR6DNP Regulates CCR6 via PARP-1, PLoS Genet. 12 (2016) e1006292.

[33] A.Y. Lee, H. Korner, CCR6 and CCL20: emerging players in the pathogenesis of rheumatoid arthritis, Immunol. Cell Biol. 92 (2014) 354-358.

[34] R.M. Strieter, M.D. Burdick, B.N. Gomperts, J.A. Belperio, M.P. Keane, CXC chemokines in angiogenesis, Cytokine Growth Factor Rev. 16 (2005) 593-609.

[35] M. Yellin, I. Paliienko, A. Balanescu, S. Ter-Vartanian, V. Tseluyko, L.A. Xu, X. Tao, P.M. Cardarelli, H. Leblanc, G. Nichol, C. Ancuta, R. Chirieac, A. Luo, A phase II, randomized, double-blind, placebocontrolled study evaluating the efficacy and safety of MDX-1100, a fully human anti-CXCL10 monoclonal antibody, in combination with methotrexate in patients with rheumatoid arthritis, Arthritis Rheum. 64 (2012) 1730-1739.

[36] P.P. Tak, A. Balanescu, V. Tseluyko, S. Bojin, E. Drescher, D. Dairaghi, S. Miao, V. Marchesin, J. Jaen, T.J. Schall, P. Bekker, Chemokine receptor CCR1 antagonist CCX354-C treatment for rheumatoid arthritis: CARAT-2, a randomised, placebo controlled clinical trial, Ann. Rheum. Dis. 72 (2013) 337-344.

[37] M. Cuchacovich, H. Gatica, S.V. Pizzo, M. Gonzalez-Gronow, Characterization of human serum dipeptidyl peptidase IV (CD26) and analysis of its autoantibodies in patients with rheumatoid arthritis and other autoimmune diseases, Clin. Exp. Rheumatol. 19 (2001) 673-680.

[38] M. Grujic, I.Z. Matic, M.D. Crnogorac, A.D. Velickovic, B. Kolundzija, O.J. Cordero, Z. Juranic, S. Prodanovic, M. Zlatanovic, D. Babic, N. Damjanov, Activity and expression of dipeptidyl peptidase IV on peripheral blood mononuclear cells in patients with early steroid and disease modifying antirheumatic drugs naive rheumatoid arthritis, Clin. Chem. Lab. Med. 55 (2017) 73-81.

[39] T. Ellingsen, N. Hornung, B.K. Moller, J. Hjelm-Poulsen, K. Stengaard-Pedersen, In active chronic rheumatoid arthritis, dipeptidyl peptidase IV density is increased on monocytes and CD4(+) T lymphocytes, Scand. J. Immunol. 66 (2007) 451-457.

[40] T. Ellingsen, I. Hansen, J. Thorsen, B. Kuno Moller, U. Tarp, S. Jacobsen, M. Lund Hetland, A. Vestergaard, K. Horslev-Petersen, K. Stengaard-Pedersen, Up-regulated dipeptidyl-peptidase IV 
(CD26) on monocytes was unaffected by effective DMARD treatment in early steroid and DMARDnaive rheumatoid arthritis, Clin. Exp. Rheumatol. 30 (2012) 58-63.

[41] H. Ulusoy, A. Kamanli, N. Ilhan, O. Kuru, S. Arslan, G. Alkan, S. Ozgocmen, Serum levels of soluble CD26 and CD30 and their clinical significance in patients with rheumatoid arthritis, Rheumatol. Int. 32 (2012) 3857-3862.

[42] J.C. Mavropoulos, M. Cuchacovich, C. Llanos, J.C. Aguillon, H. Gatica, S.V. Pizzo, M. GonzalezGronow, Anti-tumor necrosis factor-alpha therapy augments dipeptidyl peptidase IV activity and decreases autoantibodies to GRP78/BIP and phosphoglucose isomerase in patients with rheumatoid arthritis, J. Rheumatol. 32 (2005) 2116-2124.

[43] E. Solau-Gervais, F. Zerimech, R. Lemaire, C. Fontaine, G. Huet, R.M. Flipo, Cysteine and serine proteases of synovial tissue in rheumatoid arthritis and osteoarthritis, Scand. J. Rheumatol. 36 (2007) 373-377.

[44] H. Gotoh, M. Hagihara, T. Nagatsu, H. Iwata, T. Miura, Activities of dipeptidyl peptidase II and dipeptidyl peptidase IV in synovial fluid from patients with rheumatoid arthritis and osteoarthritis, Clin. Chem. 35 (1989) 1016-1018.

[45] R.X. Leng, J. Liu, X.K. Yang, B. Wang, C. Zhang, S.S. Tao, D.G. Wang, X.M. Li, X.P. Li, H.F. Pan, D.Q. Ye, Evidence of epistatic interaction between DPP4 and CCR6 in patients with rheumatoid arthritis, Rheumatology (Oxford) 55 (2016) 2230-2236.

[46] S. Struyf, P. Proost, J. Van Damme, Regulation of the immune response by the interaction of chemokines and proteases, Adv. Immunol. 81 (2003) 1-44.

[47] A.M. Lambeir, P. Proost, C. Durinx, G. Bal, K. Senten, K. Augustyns, S. Scharpé, J. Van Damme, I. De Meester, Kinetic investigation of chemokine truncation by CD26/dipeptidyl peptidase IV reveals a striking selectivity within the chemokine family, J. Biol. Chem. 276 (2001) 29839-29845.

[48] R. Janssens, A. Mortier, D. Boff, P. Ruytinx, M. Gouwy, B. Vantilt, O. Larsen, V. Daugvilaite, M.M. Rosenkilde, M. Parmentier, S. Noppen, S. Liekens, J. Van Damme, S. Struyf, M.M. Teixeira, F.A.

Amaral, P. Proost, Truncation of CXCL12 by CD26 reduces its CXC chemokine receptor 4- and atypical chemokine receptor 3-dependent activity on endothelial cells and lymphocytes, Biochem.

Pharmacol. 132 (2017) 92-101.

[49] N. Busso, N. Wagtmann, C. Herling, V. Chobaz-Péclat, A. Bischof-Delaloye, A. So, E. Grouzmann, Circulating CD26 is negatively associated with inflammation in human and experimental arthritis, Am. J. Pathol. 166 (2005) 433-442.

[50] B. Savino, E.M. Borroni, N.M. Torres, P. Proost, S. Struyf, A. Mortier, A. Mantovani, M. Locati, R. Bonecchi, Recognition versus adaptive up-regulation and degradation of $\mathrm{CC}$ chemokines by the chemokine decoy receptor D6 are determined by their N-terminal sequence, J. Biol. Chem. 284 (2009) 26207-26215.

[51] J.J. Haringman, T.J. Smeets, P. Reinders-Blankert, P.P. Tak, Chemokine and chemokine receptor expression in paired peripheral blood mononuclear cells and synovial tissue of patients with rheumatoid arthritis, osteoarthritis, and reactive arthritis, Ann. Rheum. Dis. 65 (2006) 294-300.

[52] P. Proost, E. Schutyser, P. Menten, S. Struyf, A. Wuyts, G. Opdenakker, M. Detheux, M. Parmentier, C. Durinx, A.M. Lambeir, J. Neyts, S. Liekens, P.C. Maudgal, A. Billiau, J. Van Damme, 
Amino-terminal truncation of CXCR3 agonists impairs receptor signaling and lymphocyte chemotaxis, while preserving antiangiogenic properties, Blood 98 (2001) 3554-3561.

[53] P. Proost, S. Struyf, D. Schols, C. Durinx, A. Wuyts, J.-P. Lenaerts, E. De Clercq, I. De Meester, J. Van Damme, Processing by CD26/dipeptidyl-peptidase IV reduces the chemotactic and anti-HIV-1 activity of stromal-cell-derived factor-1alpha, FEBS Lett. 432 (1998) 73-76.

[54] T. Ohtsuki, O. Hosono, H. Kobayashi, H. Munakata, A. Souta, T. Shioda, C. Morimoto, Negative regulation of the anti-human immunodeficiency virus and chemotactic activity of human stromal cell-derived factor 1alpha by CD26/dipeptidyl peptidase IV, FEBS Lett. 431 (1998) 236-240.

[55] S. Struyf, P. Menten, J.-P. Lenaerts, W. Put, A. D'Haese, E. De Clercq, D. Schols, P. Proost, J. Van Damme, Diverging binding capacities of natural LD78beta isoforms of macrophage inflammatory protein-1alpha to the CC chemokine receptors 1,3 and 5 affect their anti-HIV-1 activity and chemotactic potencies for neutrophils and eosinophils, Eur. J. Immunol. 31 (2001) 2170-2178.

[56] P. Proost, P. Menten, S. Struyf, E. Schutyser, I. De Meester, J. Van Damme, Cleavage by CD26/dipeptidyl peptidase IV converts the chemokine LD78beta into a most efficient monocyte attractant and CCR1 agonist, Blood 96 (2000) 1674-1680.

[57] E. Guan, J. Wang, M.A. Norcross, Amino-terminal processing of MIP-1beta/CCL4 by CD26/dipeptidyl-peptidase IV, J. Cell. Biochem. 92 (2004) 53-64.

[58] P. Proost, I. De Meester, D. Schols, S. Struyf, A.M. Lambeir, A. Wuyts, G. Opdenakker, E. De Clercq, S. Scharpé, J. Van Damme, Amino-terminal truncation of chemokines by CD26/dipeptidylpeptidase IV. Conversion of RANTES into a potent inhibitor of monocyte chemotaxis and HIV-1infection, J. Biol. Chem. 273 (1998) 7222-7227.

[59] S. Struyf, I. De Meester, S. Scharpé, J.-P. Lenaerts, P. Menten, J.M. Wang, P. Proost, J. Van Damme, Natural truncation of RANTES abolishes signaling through the CC chemokine receptors CCR1 and CCR3, impairs its chemotactic potency and generates a CC chemokine inhibitor, Eur. J. Immunol. 28 (1998) 1262-1271.

[60] R. Richter, P. Casarosa, L. Standker, J. Munch, J.Y. Springael, S. Nijmeijer, W.G. Forssmann, H.F. Vischer, J. Vakili, M. Detheux, M. Parmentier, R. Leurs, M.J. Smit, Significance of N-terminal proteolysis of CCL14a to activity on the chemokine receptors CCR1 and CCR5 and the human cytomegalovirus-encoded chemokine receptor US28, J. Immunol. 183 (2009) 1229-1237.

[61] J. Hu, P.E. Van den Steen, Q.X. Sang, G. Opdenakker, Matrix metalloproteinase inhibitors as therapy for inflammatory and vascular diseases, Nat. Rev. Drug. Discov. 6 (2007) 480-498.

[62] R.E. Vandenbroucke, C. Libert, Is there new hope for therapeutic matrix metalloproteinase inhibition? Nat. Rev. Drug Discov. 13 (2014) 904-927.

[63] G.S. Butler, C.M. Overal, Proteomic validation of protease drug targets: pharmacoproteomics of matrix metalloproteinase inhibitor drugs using isotope-coded affinity tag labelling and tandem mass spectrometry, Curr. Pharm. Des. 13 (2007) 263-270.

[64] B. Cauwe, P.E. Van den Steen, G. Opdenakker, The biochemical, biological, and pathological kaleidoscope of cell surface substrates processed by matrix metalloproteases, Crit Rev Biochem Mol Biol 42 (2007) 113-185. 
[65] P.E. Van den Steen, B. Dubois, I. Nelissen, P.M Rudd, R.A. Dwek, G. Opdenakker, Biochemistry and molecular biology of gelatinase B or matrix metalloproteinase-9 (MMP-9), Crit Rev Biochem Mol Biol 37 (2002) 375-536.

[66] J. Vandooren, P.E. Van den Steen, G. Opdenakker, Biochemistry and molecular biology of gelatinase B or matrix metalloproteinase-9 (MMP-9): the next decade, Crit. Rev. Biochem. Mol. Biol. 48 (2013) 222-272.

[67] M. de Bruyn, J. Vandooren, E. Ugarte-Berzal, I. Arijs, S. Vermeire, G. Opdenakker, The molecular biology of matrix metalloproteinases and tissue inhibitors of metalloproteinases in inflammatory bowel diseases, Crit. Rev. Biochem. Mol. Biol. 51 (2016) 295-358.

[68] B. Cauwe, G. Opdenakker, Intracellular substrate cleavage: a novel dimension in the biochemistry, biology and pathology of matrix metalloproteinases, Crit. Rev. Biochem. Mol. Biol. 45 (2010) 351-423.

[69] B. Cauwe, E. Martens, P. Proost, G. Opdenakker, Multidimensional degradomics identifies systemic autoantigens and intracellular matrix proteins as novel gelatinase B/MMP-9 substrates, Integr. Biol. (Camb) 1 (2009) 404-426.

[70] J. Redondo-Munoz, E. Ugarte-Berzal, M.J. Terol, P.E. Van den Steen, M. Hernandez del Cerro, M. Roderfeld, E. Roeb, G. Opdenakker, J.A. Garcia-Marco, A. Garcia-Pardo, Matrix metalloproteinase-9 promotes chronic lymphocytic leukemia b cell survival through its hemopexin domain, Cancer Cell 17 (2010) 160-172.

[71] D.J. Marchant, C.L. Bellac, T.J. Moraes, S.J. Wadsworth, A. Dufour, G.S. Butler, L.M. Bilawchuk, R.G. Hendry, A.G. Robertson, C.T. Cheung, J. Nq, L. Ang, Z. Luo, K. Heibron, M.J. Norris, W. Duan, T. Bucyk, A. Karpov, L. Devel, D. Georgiadis, R.G. Hegele, H. Luo, D.J. Granville, V. Dive, B.M. McManus, C.M. Overall, A new transcriptional role for matrix metalloproteinase-12 in antiviral immunity, Nat. Med. 20 (2014) 493-502.

[72] X. Fan, A.C. Patera, A. Pong-Kennedy, G. Deno, W. Gonsiorek, D.J. Manfra, G. Vassileva, M. Zeng, C. Jackson, L. Sullivan, W. Sharif-Rodriguez, G. Opdenakker, J. Van Damme, J.A. Hedrick, D. Lundell, S.A. Lira, R.W. Hipkin, Murine CXCR1 is a functional receptor for GCP-2/CXCL6 and interleukin8/CXCL8, J. Biol. Chem. 282 (2007) 11658-11666.

[73] A. Wuyts, N. Van Osselaer, A. Haelens, I. Samson, P. Herdewijn, A. Ben-Baruch, J. Oppenheim, P. Proost, J. Van Damme, Characterization of synthetic human granulocyte chemotactic protein 2: usage of chemokine receptors CXCR1 and CXCR2 and in vivo inflammatory properties, Biochemistry 36 (1997) 2716-2723.

[74] P.E. Van den Steen, A. Wuyts, S.J. Husson, P. Proost, J. Van Damme, G. Opdenakker, Gelatinase B/MMP-9 and neutrophil collagenase/MMP-8 process the chemokines human GCP-2/CXCL6, ENA78/CXCL5 and mouse GCP-2/LIX and modulate their physiological activities, Eur. J. Biochem. 270 (2003) 3739-3749.

[75] P.E. Van den Steen, P. Proost, A. Wuyts, J. Van Damme, G. Opdenakker, Neutrophil gelatinase B potentiates interleukin-8 tenfold by aminoterminal processing, whereas it degrades CTAP-III, PF-4, and GRO-alpha and leaves RANTES and MCP-2 intact, Blood 96 (2000) 2673-2681.

[76] P.E. Van den Steen, S.J. Husson, P. Proost, J. Van Damme, G. Opdenakker, Carboxyterminal cleavage of the chemokines MIG and IP-10 by gelatinase B and neutrophil collagenase, Biochem. Biophys. Res. Commun. 310 (2003) 889-896. 
[77] A.M. Tester, J.H. Cox, A.R. Connor, A.E. Starr, R.A. Dean, X.S. Puente, C. Lopez-Otin, C.M. Overall, LPS responsiveness and neutrophil chemotaxis in vivo require PMN MMP-8 activity, PLoS One 2 (2007) e312.

[78] A. Mortier, T. Loos, M. Gouwy, I. Ronsse, J. Van Damme, P. Proost, Posttranslational modification of the $\mathrm{NH}_{2}$-terminal region of $\mathrm{CXCL} 5$ by proteases or peptidylarginine deiminases (PAD) differently affects its biological activity, J. Biol. Chem. 285 (2010) 29750-29759.

[79] R.A. Dean, J.H. Cox, C.L. Bellac, A. Doucet, A.E. Starr, C.M. Overall, Macrophage-specific metalloelastase (MMP-12) truncates and inactivates ELR+ CXC chemokines and generates CCL2, -7, 8 , and -13 antagonists: potential role of the macrophage in terminating polymorphonuclear leukocyte influx, Blood 112 (2008) 3455-3464.

[80] J.H. Cox, R.A. Dean, C.R. Roberts, C.M. Overall, Matrix metalloproteinase processing of CXCL11/I-TAC results in loss of chemoattractant activity and altered glycosaminoglycan binding, J. Biol. Chem. 283 (2008) 19389-19399.

[81] K. Zhang, G.A. McQuibban, C. Silva, G.S. Butler, J.B. Johnston, J. Holden, I. Clark-Lewis, C.M. Overall, C. Power, HIV-induced metalloproteinase processing of the chemokine stromal cell derived factor-1 causes neurodegeneration, Nat. Neurosci. 6 (2003) 1064-1071.

[82] G.A. McQuibban, J.H. Gong, E.M. Tam, C.A. McCulloch, I. Clark-Lewis, C.M. Overall, Inflammation dampened by gelatinase A cleavage of monocyte chemoattractant protein-3, Science 289 (2000) 1202-1206.

[83] G.A. McQuibban, J.H. Gong, J.P. Wong, J.L. Wallace, I. Clark-Lewis, C.M. Overall, Matrix metalloproteinase processing of monocyte chemoattractant proteins generates CC chemokine receptor antagonists with anti-inflammatory properties in vivo, Blood 100 (2002) 1160-1167.

[84] R.A. Dean, C.M. Overall, Proteomics discovery of metalloproteinase substrates in the cellular context by iTRAQ labeling reveals a diverse MMP-2 substrate degradome, Mol. Cell. Proteomics 6 (2007) 611-623.

[85] K. Endo, T. Takino, H. Miyamori, H. Kinsen, T. Yoshizaki, M. Furukawa, H. Sato, Cleavage of syndecan-1 by membrane type matrix metalloproteinase-1 stimulates cell migration, J. Biol. Chem. 278 (2003) 40764-40770.

[86] S. Brule, N. Charnaux, A. Sutton, D. Ledoux, T. Chaigneau, L. Saffar, L. Gattegno L, The shedding of syndecan- 4 and syndecan- 1 from HeLa cells and human primary macrophages is accelerated by SDF-1/CXCL12 and mediated by the matrix metalloproteinase-9, Glycobiology 16 (2006) 488-501.

[87] A. Li, P.W. Park, C.L. Wilson, W.C. Parks, Matrilysin shedding of syndecan-1 regulates chemokine mobilization and transepithelial efflux of neutrophils in acute lung injury, Cell 111 (2002) 635-646.

[88] J. Song, C. Wu, E. Korpos, X. Zhang, S.M. Agrawal, Y. Wang, C. Faber, M. Schafers, H. Korner, G. Opdenakker, R. Hallmann, L. Sorokin, Focal MMP-2 and MMP-9 activity at the blood-brain barrier promotes chemokine-induced leukocyte migration, Cell Rep. 10 (2015) 1040-1054.

[89] M.P. Quinones, Y. Kalkonde, C.A. Estrada, F. Jimenez, R. Ramirez, L. Mahimainathan, S. Mummidi, G.G. Choudhury, H. Martinez, L. Adams, M. Mack, R.L. Reddick, S. Maffi, S. Haralambous, L. Probert, S.J. Ahuja, S.S. Ahuja, Role of astrocytes and chemokine systems in acute TNFalpha induced demyelinating syndrome: CCR2-dependent signals promote astrocyte activation and survival via NF-kappaB and Akt, Mol. Cell. Neurosci. 37 (2008) 96-109. 
[90] W.L. Thompson, L.J. Van Eldik, Inflammatory cytokines stimulate the chemokines CCL2/MCP-1 and CCL7/MCP-3 through NFkB and MAPK dependent pathways in rat astrocytes, Brain Res. 1287 (2009) 47-57.

[91] E.E. McCandless, Q. Wang, B.M. Woerner, J.M. Harper, R.S. Klein, CXCL12 limits inflammation by localizing mononuclear infiltrates to the perivascular space during experimental autoimmune encephalomyelitis, J. Immunol. 177 (2006) 8053-8064.

[92] D.B. Corry, A. Kiss, L.Z. Song, L. Song, J. Xu, S.H. Lee, Z. Werb, F. Kheradmand, Overlapping and independent contributions of MMP 2 and MMP9 to lung allergic inflammatory cell egression through decreased CC chemokines, FASEB. J. 18 (2004) 995-997.

[93] B. Cauwe, E. Martens, X. Sagaert, C. Dillen, N. Geurts, S. Li, J. Mertens, G. Thijs, P.E. Van den Steen, H. Heremans, R. De Vos, D. Blockmans, B. Arnold, G. Opdenakker, Deficiency of gelatinase B/MMP-9 aggravates Ipr-induced lymphoproliferation and lupus-like systemic autoimmune disease, J. Autoimmun. 36 (2011) 239-252.

[94] H. Kaneko, H. Ogasawara, T. Naito, H. Akimoto, S. Lee, T. Hishikawa, I. Sekigawa, Y. Tokano, Y. Takasaki, S.I. Hirose, H. Hashimoto, Circulating levels of beta-chemokines in systemic lupus erythematosus, J. Rheumatol. 26 (1999) 568-573.

[95] N. likuni, H. Okamoto, T. Yoshio, E. Sato, S. Kamitsuji, T. Iwamoto, S. Momohara, A. Taniguchi, H. Yamanaka, S. Minota S, N. Kamatani, Raised monocyte chemotactic protein-1 (MCP-1)/CCL2 in cerebrospinal fluid of patients with neuropsychiatric lupus, Ann. Rheum. Dis. 65 (2006) 253-256.

[96] T.J. Schall, K. Bacon, K.J. Toy, D.V. Goeddel, Selective attraction of monocytes and T lymphocytes of the memory phenotype by cytokine RANTES, Nature 347 (1990) 669-671.

[97] R.W. Chan, L.S. Tam, E.K. Li, F.M. Lai, K.M. Chow, K.B. Lai, P.K. Li, C.C. Szeto, Inflammatory cytokine gene expression in the urinary sediment of patients with lupus nephritis, Arthritis Rheum. 48 (2003) 1326-1331.

[98] K.J. Moore, T. Wada, S.D. Barbee, V.R. Kelley, Gene transfer of RANTES elicits autoimmune renal injury in MRL-Fas(1pr) mice, Kidney Int. 53 (1998) 1631-1641.

[99] A. Zlotnik, O. Yoshie, Chemokines: a new classification system and their role in immunity, Immunity 12 (2000) 121-127.

[100] P. Schaerli, K. Willimann, A.B. Lang, M. Lipp, P. Loetscher, B. Moser, CXC chemokine receptor 5 expression defines follicular homing T cells with B cell helper function, J. Exp. Med. 192 (2000) 15531562.

[101] L.C. Lit, C.K. Wong, L.S. Tam, E.K. Li, C.W. Lam, Raised plasma concentration and ex vivo production of inflammatory chemokines in patients with systemic lupus erythematosus, Ann. Rheum. Dis. 65 (2006) 209-215.

[102] P.M. Rudd, R.A. Dwek, Glycosylation: heterogeneity and the 3D structure of proteins, Crit. Rev. Biochem. Mol. Biol. 32 (1997) 1-100.

[103] P. Van den Steen, P.M. Rudd, R.A. Dwek, G. Opdenakker, Concepts and principles of O-linked glycosylation, Crit. Rev. Biochem. Mol. Biol. 33 (1998) 151-208. 
[104] P.M. Rudd, H.C. Joao, E. Coghill, P. Fiten, M.R. Saunders, G. Opdenakker, R.A. Dwek, Glycoforms modify the dynamic stability and functional activity of an enzyme, Biochemistry 33 (1994) 17-22.

[105] P.M. Rudd, R.J. Woods, M.R. Wormald, G. Opdenakker, A.K. Downing, I.D. Campbell, R.A. Dwek, The effects of variable glycosylation on the functional activities of ribonuclease, plasminogen and tissue plasminogen activator, Biochim. Biophys. Acta 1248 (1995) 1-10.

[106] A. Mortier, J. Van Damme, P. Proost, Overview of the mechanisms regulating chemokine activity and availability, Immunol. Lett. 145 (2012) 2-9.

[107] G.P. Livi, J.S. Lillquist, L.M. Miles, A. Ferrara, G.M. Sathe, P.L. Simon, C.A. Meyers, J.A. Gorman, P.R. Young, Secretion of N-glycosylated interleukin-1 beta in Saccharomyces cerevisiae using a leader peptide from Candida albicans. Effect of N-linked glycosylation on biological activity, J. Biol. Chem. 266 (1991) 15348-15355.

[108] G. Opdenakker, P.M. Rudd, M. Wormald, R.A. Dwek, J. Van Damme, Cells regulate the activities of cytokines by glycosylation, FASEB J. 9 (1995) 453-457.

[109] R. Okamoto, K. Mandal, M.R. Sawaya, Y. Kajihara, Y.O. Yeates, S.B. Kent, (Quasi-)racemic X-ray structures of glycosylated and non-glycosylated forms of the chemokine Ser-CCL1 prepared by total chemical synthesis, Angew. Chem. Int. Ed. Engl. 53 (2014) 5194-5198.

[110] A.M. Durkan, R.T. Alexander, G.Y. Liu, M. Rui, G. Femia, L.A. Robinson, Expression and targeting of CX3CL1 (fractalkine) in renal tubular epithelial cells, J. Am. Soc. Nephrol. 18 (2007) 74-83.

[111] J. Van Damme, B. Decock, R. Bertini, C. Conings, J.-P. Lenaerts, W. Put, G. Opdenakker, A. Mantovani A, Production and identification of natural monocyte chemotactic protein from virally infected murine fibroblasts. Relationship with the product of the mouse competence (JE) gene, Eur. J. Biochem. 199 (1991) 223-229.

[112] C.A. Ernst, Y.J. Zhang, P.R. Hancock, B.J. Rutledge, C.L. Corless, B.J. Rollins, Biochemical and biologic characterization of murine monocyte chemoattractant protein-1. Identification of two functional domains, J. Immunol. 152 (1994) 3541-3549.

[113] Y. Jiang, A.J. Valente, M.J. Williamson, L. Zhang, D.T. Graves, Post-translational modification of a monocyte-specific chemoattractant synthesized by glioma, osteosarcoma, and vascular smooth muscle cells, J. Biol. Chem. 265 (1990) 18318-18321.

[114] P. Ruggiero, S. Flati, V. Di Cioccio, G. Maurizi, G. Macchia, A. Facchin, R. Anacardio, A. Maras, M. Lucarelli, D. Boraschi, Glycosylation enhances functional stability of the chemotactic cytokine CCL2, Eur. Cytokine Netw. 14 (2003) 91-96.

[115] L.A. Marcaurelle, L.S. Mizoue, J. Wilken, L. Oldham, S.B. Kent, T.M. Handel, C.R. Bertozzi, Chemical synthesis of lymphotactin: a glycosylated chemokine with a C-terminal mucin-like domain, J. Biol. Chem. 265 (1990) 18318-18321.

[116] J. Blaszczyk, E. Van Coillie, P. Proost, J. Van Damme, G. Opdenakker, G.D. Bujacz, J.M. Wang, X. $\mathrm{Ji}$, Complete crystal structure of monocyte chemotactic protein-2, a CC chemokine that interacts with multiple receptors, Biochemistry 39 (2000) 14075-14081.

[117] G.M. Clore, E. Appella, M. Yamada, K. Matsushima, A.M. Gronenborn, Three-dimensional structure of interleukin 8 in solution, Biochemistry 29 (1990) 1689-1696. 
[118] E.T. Baldwin, I.T. Weber, R. St Charles, J.C. Xuan, E. Appella, M. Yamada, K. Matsushima, B.F. Edwards, G.M. Clore, A.M. Gronenborn, A. Wlodawer, Crystal structure of interleukin 8: symbiosis of NMR and crystallography, Proc. Natl. Acad. Sci. U S A 88 (1991) 502-506.

[119] L. Wang, M. Fuster, P. Sriramarao, J.D. Esko, Endothelial heparan sulfate deficiency impairs Lselectin- and chemokine-mediated neutrophil trafficking during inflammatory responses, Nat. Immunol. 6 (2005) 902-910.

[120] A.E. Proudfoot, T.M. Handel, Z. Johnson, E.K. Lau, P. LiWang, I. Clark-Lewis, F. Borlat, T.N. Wells, M.H. Kosco-Vilbois, Glycosaminoglycan binding and oligomerization are essential for the in vivo activity of certain chemokines, Proc. Natl. Acad. Sci. U S A 100 (2003) 1885-1890.

[121] M. Sarris, J.B. Masson, D. Maurin, L.M. Van der Aa, P. Boudinot, H. Lortat-Jacob, P. Herbomel, Inflammatory chemokines direct and restrict leukocyte migration within live tissues as glycan-bound gradients, Curr. Biol. 22 (2012) 2375-2382.

[122] S. Massena, G. Christoffersson, E. Hjertström, E. Zcharia, I. Vlodavsky, N. Ausmees, C. Rolny, J.P. Li, M. Phillipson, A chemotactic gradient sequestered on endothelial heparan sulfate induces directional intraluminal crawling of neutrophils, Blood 116 (2010) 1924-1931.

[123] X. Bao, E.A. Moseman, H. Saito, B. Petryniak, A. Thiriot, S. Hatakeyama, Y. Ito, H. Kawashima, Y. Yamaguchi, J.B. Lowe, U.H. von Andrian, M. Fukuda, Endothelial heparan sulfate controls chemokine presentation in recruitment of lymphocytes and dendritic cells to lymph nodes, Immunity 33 (2010) 817-829.

[124] F. Verkaar, J. van Offenbeek, M.M. van der Lee, L.H. van Lith, A.O. Watts, A.L. Rops, D.C. Aguilar, J.J. Ziarek, J. van der Vlag, T.M. Handel, B.F. Volkman, A.E. Proudfoot, H.F. Vischer, G.J. Zaman, M.J. Smit, Chemokine cooperativity is caused by competitive glycosaminoglycan binding, J. Immunol. 192 (2014) 3908-3914.

[125] D.P. Dyer, C.L. Salanga, B.F. Volkman, T. Kawamura, T.M. Handel, The dependence of chemokine-glycosaminoglycan interactions on chemokine oligomerization, Glycobiology 26, 2016, 312-326.

[126] G.M. Hjortø, O. Larsen, A. Steen , V. Daugvilaite, C. Berg, S. Fares, M. Hansen, S. Ali, M.M. Rosenkilde, Differential CCR7 targeting in dendritic cells by three naturally occurring CC-chemokines, Front. Immunol. 7 (2016) 568.

[127] B.J. Connell, R. Sadir, F. Baleux, C. Laguri, J.P. Kleman, L. Luo, F. Arnezana-Seisdedos, H. LortatJacob, Heparan sulfate differentially controls CXCL12 $\alpha$ - and CXCL12 $\gamma$-mediated cell migration through differential presentation to their receptor CXCR4. Sci. Signal. 9 (2016) ra107.

[128] V. Vanheule, R. Janssens, D. Boff, N. Kitic, N. Berghmans, I. Ronsse, A.J. Kungl, F.A. Amaral, M.M. Teixiera, J. Van Damme, P. Proost, A. Mortier, The positively charged $\mathrm{COOH}$-terminal glycosaminoglycan-binding CXCL9(74-103) peptide inhibits CXCL8-induced neutrophil extravasation and monosodium urate crystal-induced gout in mice, J. Biol. Chem. 290 (2015) 21292-21304.

[129] V. Vanheule, P. Vervaeke, A. Mortier, S. Noppen, M. Gouwy, R. Snoeck, G. Andrei, J. Van Damme, S. Liekens, P. Proost, Basic chemokine-derived glycosaminoglycan binding peptides exert antiviral properties against dengue virus serotype 2 , herpes simplex virus- 1 and respiratory syncytial virus. Biochem. Pharmacol. 100 (2016) 73-85. 
[130] V. Vanheule, D. Boff, A. Mortier, R. Janssens, B. Petri, E. Kolaczkowska, P. Kubes, N. Berghmans, S. Struyf, A.J. Kungl, M.M. Teixeira, F.A. Amaral, P. Proost, CXCL9-derived peptides differentially inhibit neutrophil migration in vivo through interference with glycosaminoglycan interactions, Front. Immunol. 8 (2017) 530.

[131] J. Wang, G.J. Babcock, H. Choe, M. Farzan, J. Sodroski, D. Gabuzda, N-linked glycosylation in the CXCR4 N-terminus inhibits binding to HIV-1 envelope glycoproteins, Virology 324 (2004) 140-150.

[132] C.T. Veldkamp, C. Seibert, F.C. Peterson, N.B. De la Cruz, J.C. $3^{\text {rd }}$ Haugner, H. Basnet, T.P. Sakmar, B.F. Volkman, Structural basis of CXCR4 sulfotyrosine recognition by the chemokine SDF/CXCL12, Sci. Signal. 16 (2008) ra4.

[133] A. Ludwig, J.E. Ehlert, H.D. Flad, E. Brandt, Identification of distinct surface-expressed and intracellular CXC-chemokine receptor 2 glycoforms in neutrophils: $\mathrm{N}$-glycosylation is essential for maintenance of receptor surface expression, J. Immunol. 165 (2000) 1044-1052.

[134] N. Bannert, S. Craig, M. Farzan, D. Sogah, N.V. Santo, H. Choe, J. Sodroski, Sialylated O-glycans and sulfated tyrosines in the $\mathrm{NH}_{2}$-terminal domain of $\mathrm{CC}$ chemokine receptor 5 contribute to high affinity binding of chemokines, J. Exp. Med. 194 (2001) 1661-1673.

[135] Y. Furutani, H. Nomura, M. Notake, Y. Oyamada, T. Fukui, M. Yamada, C.G. Larsen, J.J. Oppenheim, K. Matsushima, Cloning and sequencing of the cDNA for human monocyte chemotactic and activating factor (MCAF), Biochem. Biophys. Res. Commun. 159 (1989) 249-255.

[136] B.J. Rollins, P. Stier, T. Ernst, G.G. Wong, The human homolog of the JE gene encodes a monocyte secretory protein, Mol. Cell Biol. 9 (1989) 4687-4695.

[137] T. Yoshimura, N. Yuhki, S.K. Moore, E. Appella, M.I. Lerman, E.J. Leonard, Human monocyte chemoattractant protein-1 (MCP-1). Full-length cDNA cloning, expression in mitogen-stimulated blood mononuclear leukocytes, and sequence similarity to mouse competence gene JE, FEBS Lett. 244 (1989) 487-493.

[138] E.A. Robinson, T. Yoshimura, E.J. Leonard, S. Tanaka, P.R. Griffin, J. Shabanowitz, D.F. Hunt, E. Appella, Complete amino acid sequence of a human monocyte chemoattractant, a putative mediator of cellular immune reactions, Proc. Natl. Acad. Sci. USA 86 (1989) 1850-1854.

[139] H.C. Chang, F. Hsu, G.J. Freeman, J.D. Griffin, E.L. Reinherz, Cloning and expression of a gamma-interferon-inducible gene in monocytes: a new member of a cytokine gene family, Int. Immunol. 1 (1989) 388-397.

[140] J. Van Damme, P. Proost, J.-P. Lenaerts, G. Opdenakker, Structural and functional identification of two human, tumor-derived monocyte chemotactic proteins (MCP-2 and MCP-3) belonging to the chemokine family, J. Exp. Med. 176 (1992) 59-65.

[141] M. Uguccioni, P. Loetscher, U. Forssmann, B. Dewald, H. Li, S.H. Lima, Y. Li, B. Krieber, G. Garotta, M. Thelen, M. Baggiolini, Monocyte chemotactic protein 4 (MCP-4), a novel structural and functional analogue of MCP-3 and eotaxin, J. Exp. Med. 183 (1996) 2379-2384.

[142] A. Becker, R. Eichentopf, R. Sedlmeier, A. Waniek, H. Cynis, B. Koch, A. Stephan, C. Bäuscher, S. Kohlmann, T. Hoffmann, A. Kehlen, S. Berg, E.J. Freyse, A. Osmand, A.C. Plank, S. Roßner, S. von Hörsten, S. Graubner, H.U. Demuth, S. Schilling, IsoQC (QPCTL) knock-out mice suggest differential substrate conversion by glutaminyl cyclase isoenzymes, Biol. Chem. 397 (2016) 45-55. 
[143] H. Cynis, T. Hoffmann, D. Friedrich, A. Kehlen, K. Gans, M. Kleinschmidt, J.U. Rahfeld, R. Wolf, M. Wermann, A. Stephan, M. Haegele, R. Sedlmeier, S. Graubner, W. Jagla, A. Müller, R. Eichentopf, U. Heiser, F. Seifert, P. H. Quax, M.R. de Vries, I. Hesse, D. Trautwein, U. Wollert, S. Berg, E.J. Freyse, S. Schilling, H.U. Demuth, The isoenzyme of glutaminyl cyclase is an important regulator of monocyte infiltration under inflammatory conditions, EMBO Mol. Med. 3 (2011) 545-558.

[144] E. Van Coillie, P. Proost, I. Van Aelst, S. Struyf, M. Polfliet, I. De Meester, D.J. Harvey, J. Van Damme, G. Opdenakker, Functional comparison of two human monocyte chemotactic protein-2 isoforms, role of the amino-terminal pyroglutamic acid and processing by CD26/ dipeptidyl peptidase IV, Biochemistry 37 (1989) 12672-12680.

[145] Y.L. Chen, K.F. Huang, W.C. Kuo, Y.C. Lo, Y.M. Lee, A.H. Wang, Inhibition of glutaminyl cyclase attenuates cell migration modulated by monocyte chemoattractant proteins, Biochem. J. 442 (2012) 403-412.

[146] J. Van Damme, J. Van Beeumen, R. Conings, B. Decock, A. Billiau, Purification of granulocyte chemotactic peptide/interleukin-8 reveals $\mathrm{N}$-terminal sequence heterogeneity similar to that of beta-thromboglobulin, Eur. J. Biochem. 181 (1989) 337-344.

[147] C.A. Hébert, F.W. Luscinskas, J.M. Kiely, E.A. Luis, W.C. Darbonne, G.L. Bennett, C.C. Liu, M.S. Obin, M.A. Jr Gimbrone, J.B. Baker, Endothelial and leukocyte forms of IL-8. Conversion by thrombin and interactions with neutrophils, J. Immunol. 145 (1990) 3033-3040.

[148] P. Proost, T. Loos, A. Mortier, E. Schutyser, M. Gouwy, S. Noppen, C. Dillen, I. Ronsse, R. Conings, S. Struyf, G. Opdenakker, P.C. Maudgal, J. Van Damme, Citrullination of CXCL8 by peptidylarginine deiminase alters receptor usage, prevents proteolysis, and dampens tissue inflammation, J. Exp. Med. 205 (2008) 2085-2097.

[149] T. Loos, G. Opdenakker, J. Van Damme, P. Proost, Citrullination of CXCL8 increases this chemokine's ability to mobilize neutrophils into the blood circulation, Heamatologica 94 (2009) 1346-1353.

[150] T. Loos, A. Mortier, M. Gouwy, I. Ronsse, W. Put, J.-P. Lenaerts, J. Van Damme, P. Proost, Citrullination of CXCL10 and CXCL11 by peptidylarginine deiminase: a naturally occurring posttranslational modification of chemokines and new dimension of immunoregulation. Blood 112 (2008) 2648-2656.

[151] K. Yoshida, O. Korchynskyi, P.P. Tak, T. Isozaki, J.H. Ruth, P.L. Campbell, D.L. Baeten, D.M. Gerlag, M.A. Amin, A.E. Koch, Citrullination of epithelial-activating peptide $78 / C X C / 5$ results in conversion from a non-monocyte-recruiting chemokine to a monocyte-recruiting chemokine, Arthritis Rheumatol. 66 (2014) 2716-2727.

[152] S. Struyf, S. Noppen, T. Loos, A. Mortier, M. Gouwy, H. Verbeke, D. Huskens, S. Luangsay, M. Parmentier, K. Geboes, D. Schols, J. Van Damme, P. Proost, Citrullination of CXCL12 differentially reduces CXCR4 and CXCR7 binding with loss of inflammatory and anti-HIV-1 activity via CXCR4, J. Immunol. 182 (2009) 666-674.

[153] G.A. Schellekens, B.A. de Jong, F.H. van den Hoogen, L.B. van de Putte, W.J. Venrooij, Citrulline is an essential constituent of antigenic determinants recognized by rheumatoid arthritis-specific autoantibodies, J. Clin. Invest. 101 (1998) 273-281.

[154] J. Dekkers, R.E. Toes, T.W. Huizinga, D. van der Woude, The role of anticitrullinated protein antibodies in the early stages of rheumatoid arthritis, Curr. Opin. Rheumatol. 28 (2016) 275-281. 
[155] C. Foulquier, M. Sebbag, C. Clavel, S. Chapuy-Regaud, R. Al Badine, M.C. Méchin, C. Vincent, R. Nachat, M. Yamada, H. Takahara, M. Simon, M. Guerrin, G. Serre, Peptidyl arginine deiminase type 2 (PAD-2) and PAD-4 but not PAD-1, PAD-3, and PAD-6 are expressed in rheumatoid arthritis synovium in close association with tissue inflammation, Arthritis Rheum. 56 (2007) 3541-3553.

[156] P. Li, M. Li, M.R. Lindberg, M.J. Kennett, N. Xiong, Y. Wang, PAD4 is essential for antibacterial innate immunity mediated by neutrophil extracellular traps, J. Exp. Med. 207 (2010) 1853-1862.

[157] M. Bawadekar, D. Shim, C.J. Johnson, T.F. Warner, R. Rebernick, D. Damgaard, C.H. Nielsen, G.J.M. Pruijn, J.E. Nett, M.A. Shelef, Peptidylarginine deiminase 2 is required for tumor necrosis factor alpha-induced citrullination and arthritis, but not neutrophil extracellular trap formation, $\mathrm{J}$. Autoimmun. 80 (2017) 39-47.

[158] E. Corsiero, F. Pratesi, E. Prediletto, M. Bombardieri, P. Migliorini, NETosis as source of autoantigens in rheumatoid arthritis, Front. Immunol. 7 (2016) 485.

[159] M.A. Moscarello, D.D. Wood, C. Ackerley, C. Boulias, Meylin in multiple sclerosis is developmentally immature, J. Clin. Invest. 94 (1994) 146-154.

[160] A.P. Nicholas, T. Sambandam, J.D. Echols, W.W. Tourtellotte, Increased citrullinated glial fibrillary acidic protein in secondary progressive multiple sclerosis, J. Com. Neurol. 473 (2004) 128136.

[161] D.D. Wood, J.M. Bilbao, P. O'Connors, M.A. Moscarello, Acute multiple sclerosis (Marburg type) is associated with developmentally immature myelin basic protein, Ann. Neurol. 40 (1996) 1824.

[162] F.G. Mastronardi, D.D. Wood, J. Mei, R. Raijmaekers, V. Tseveleki, H.M. Dosch, L. Probert, P. Casaccia-Bonnefil, M.A. Moscarello, Increased citrullination of histone H3 in multiple sclerosis brain and animal models of demyelination: a role for tumor necrosis factor-induced peptidylarginine deiminase 4 translocation, J. Neurosci. 26 (2006) 11387-11396.

[163] D.D. Wood, C.A. Ackerley, B.v. Brand, L. Zhang, R. Raijmakers, F.G. Mastronardi, M.A. Moscarello, Myelin localization of peptidylarginine deiminases 2 and 4: comparison of PAD2 and PAD4 activities, Lab. Invest. 88 (2008) 354-364.

[164] J. De Keyser, M. Schaaf, A. Teelken, Peptidylarginine deiminase activity in postmortem white matter of patients with multiple sclerosis, Neurosci. Lett. 260 (1999) 74-76.

[165] L. Wei, E. Wasilewski, S.K. Chakka, A.M. Bello, M.A. Moscarello, L.P. Kotra, Novel inhibitors of protein arginine deiminase with potential activity in multiple sclerosis animal model, J. Med. Chem. 56 (2013) 1715-1722.

[166] E. Sato, K.L. Simpson, M.B. Grisham, S. Koyama, R.A. Robbins, Effects of reactive oxygen and nitrogen metabolites on MCP-1-induced monocyte chemotactic activity in vitro, Am. J. Physiol. 277 (1999) L543-L549.

[167] B. Molon, S. Ugel, F. Del Pozzo, C. Soldani, S. Zilio, D. Avella, A. De Palma, R. Mauri, A. Monegal, M. Rescigno, B. Savino, P. Colombo, N. Jonjic, S. Pecanic, L. Lazzarato, R. Fruttero, A. Gasco, V. Bronte, A. Viola, Chemokine nitration prevents intratumoral infiltration of antigen-specific T cells, J. Exp. Med. 208 (2011) 1949-1962.

[168] C.E. Barker, S. Thompson, G. O’Boyle, H. Lortat-Jacob, N.S. Sheerin, S. Ali, J.A. Kirby, CCL2 nitration is a negative regulator of chemokine-mediated inflammation, Sci. Rep. 7 (2017) 44384. 
[169] R. Janssens, A. Mortier, D. Boff, V. Vanheule, M. Gouwy, C. Franck, O. Larsen, M.M. Rosenkilde, J. Van Damme, F.A. Amaral, M.M. Teixeira, S. Struyf, P. Proost, Natural nitration of CXCL12 reduces its signaling capacity and chemotactic activity in vitro and abrogates intra-articular lymphocyte recruitment in vivo, Oncotarget 7 (2016) 62439-62459. 
Supplementary Table 1

Human $\mathrm{CCL}$

\begin{tabular}{|c|c|c|c|c|c|c|c|}
\hline $\begin{array}{l}\text { Entry } \\
\text { name }\end{array}$ & Entry & Length & $\begin{array}{l}\text { Nglyc } \\
\mathrm{V} / \mathrm{T}\end{array}$ & Pos & $\begin{array}{l}\text { Oglyc } \\
\text { V/T }\end{array}$ & Pos & Ref \\
\hline CCL1 & P22362 & 96 & $0 / 1$ & 52 & $0 / 0$ & & \\
\hline $\mathrm{CCL} 2$ & P13500 & 99 & $1 / 1$ & 37 & $1 / 0$ & $?$ & 1,2 \\
\hline CCL3 & P10147 & 92 & $0 / 0$ & & $0 / 0$ & & \\
\hline$\overline{C C L 3 L 1}$ & P16619 & 93 & $0 / 0$ & & $0 / 0$ & & \\
\hline CCL4 & P13236 & 92 & $0 / 0$ & & $0 / 0$ & & \\
\hline$\overline{C C L 4 L}$ & Q8NHW4 & 92 & $0 / 0$ & & $0 / 0$ & & \\
\hline CCL5 & P13501 & 91 & $0 / 0$ & & $2 / 0$ & 27,28 & 3 \\
\hline CCL7 & P80098 & 99 & $0 / 1$ & 29 & $0 / 0$ & & \\
\hline CCL8 & P80075 & 99 & $0 / 0$ & & $0 / 0$ & & \\
\hline CCL11 & P51671 & 97 & $0 / 0$ & & $1 / 0$ & 94 & 4 \\
\hline CCL13 & Q99616 & 98 & $0 / 0$ & & $0 / 0$ & & \\
\hline CCL14 & Q16627 & 93 & $0 / 1$ & 76 & $1 / 2$ & 25,26 & 5 \\
\hline CCL15 & Q16663 & 113 & $0 / 0$ & & $0 / 0$ & & \\
\hline CCL16 & 015467 & 120 & $0 / 1$ & 100 & $0 / 4$ & $98,102,103,108$ & \\
\hline CCL17 & Q92583 & 94 & $0 / 0$ & & $0 / 0$ & & \\
\hline CCL18 & P55774 & 89 & $0 / 0$ & & $0 / 0$ & & \\
\hline CCL19 & Q99731 & 98 & $0 / 0$ & & $0 / 3$ & $15,89,90$ & \\
\hline CCL20 & P78556 & 96 & $0 / 0$ & & $0 / 0$ & & \\
\hline CCL21 & 000585 & 134 & $0 / 0$ & & $0 / 8$ & $93,95,110,112,119,125,128,130$ & \\
\hline CCL22 & 000626 & 93 & $0 / 0$ & & $0 / 0$ & & \\
\hline CCL23 & P55773 & 120 & $0 / 1$ & 96 & $0 / 1$ & 51 & \\
\hline CCL24 & 000175 & 119 & $0 / 1$ & 115 & $0 / 1$ & 97 & \\
\hline CCL25 & 015444 & 150 & $0 / 1$ & 139 & $0 / 12$ & $\begin{array}{l}104,106,118,119,122,125,126,127,130,134 \\
135,136\end{array}$ & \\
\hline CCL26 & Q9Y258 & 94 & $0 / 0$ & & $0 / 1$ & 66 & \\
\hline CCL27 & Q9Y4X3 & 112 & $0 / 1$ & 82 & $0 / 1$ & 30 & \\
\hline CCL28 & Q9NRJ3 & 127 & $0 / 1$ & 78 & $0 / 2$ & 110,120 & \\
\hline
\end{tabular}


Human CXCL

\begin{tabular}{|l|l|l|l|l|l|l|l|}
\hline $\begin{array}{l}\text { Entry } \\
\text { name }\end{array}$ & Entry & Length & $\begin{array}{l}\text { Nglyc } \\
\text { V/T }\end{array}$ & Pos & $\begin{array}{l}\text { Oglyc } \\
\text { V/T }\end{array}$ & Pos & Ref \\
\hline CXCL1 & P09341 & 107 & $0 / 0$ & & $0 / 1$ & 7 & \\
\hline CXCL2 & P19875 & 107 & $0 / 0$ & & $0 / 2$ & 5,7 & \\
\hline CXCL3 & P19876 & 107 & $0 / 0$ & & $0 / 2$ & 5,7 & \\
\hline CXCL4 & P02776 & 101 & $0 / 0$ & & $0 / 0$ & & \\
\hline CXCL4V1 & P10720 & 104 & $0 / 0$ & & $0 / 3$ & $2,3,7$ & \\
\hline CXCL5 & P42830 & 114 & $0 / 0$ & & $0 / 3$ & $2,5,6$ & \\
\hline CXCL6 & P80162 & 114 & $0 / 0$ & & $0 / 4$ & $2,5,6,55$ & \\
\hline CXCL7 & P02775 & 128 & $0 / 0$ & & $0 / 4$ & $2,8,10,13$ & \\
\hline CXCL8 & P10145 & 99 & $0 / 0$ & & $0 / 0$ & & \\
\hline CXCL9 & Q07325 & 125 & $0 / 0$ & & $0 / 0$ & & \\
\hline CXCL10 & P02778 & 98 & $0 / 1$ & 2 & $0 / 1$ & 90 & \\
\hline CXCL11 & O14625 & 94 & $0 / 0$ & & $0 / 0$ & & \\
\hline CXCL12 & P48061 & 93 & $0 / 0$ & & $0 / 0$ & & \\
\hline CXCL13 & O43927 & 109 & $0 / 1$ & 71 & $0 / 4$ & $95,96,97,98$ & \\
\hline CXCL14 & O95715 & 111 & $0 / 0$ & & $0 / 1$ & 2 & \\
\hline CXCL16 & Q9H2A7 & 254 & $0 / 1$ & 168 & $0 / 20$ & $119,120,124,127,131,132,136,143,144,147$, & \\
\hline CXCL17 & Q6UXB2 & 119 & $0 / 0$ & & $0 / 5$ & $39,66,68,87,108$ & \\
\hline
\end{tabular}

Human XCL, X3CL

\begin{tabular}{|c|c|c|c|c|c|c|c|}
\hline Entry name & Entry & Length & $\begin{array}{l}\text { Nglyc } \\
\mathrm{V} / \mathrm{T}\end{array}$ & Pos & $\begin{array}{l}\text { Oglyc } \\
\mathrm{V} / \mathrm{T}\end{array}$ & Pos & Ref \\
\hline XCL1 & P47992 & 114 & $0 / 0$ & & $0 / 13$ & $\begin{array}{l}34,36,37,43,83,88,90,97,100,102,105,106, \\
108\end{array}$ & \\
\hline XCL2 & Q9UBD3 & 114 & $0 / 0$ & & $0 / 14$ & $\begin{array}{l}31,34,36,37,43,83,88,90,97,100,102,105 \\
106,108\end{array}$ & \\
\hline X3CL1 & P78423 & 397 & $0 / 1$ & 33 & $3 / 52$ & $\begin{array}{l}97,102,114,115,124,132,135,136,137,141, \\
143,144,153,154,159,162,164,165,167,172, \\
183,192,193,196,199,200,208,215,216,220, \\
221,225,226,229,230,232,233,242,253,259, \\
272,282,287,292,293,296,298,304,306,308, \\
318,329\end{array}$ & $\begin{array}{l}6 \\
6,7 \\
6,7\end{array}$ \\
\hline
\end{tabular}


Mouse CCL

\begin{tabular}{|c|c|c|c|c|c|c|c|}
\hline $\begin{array}{l}\text { Entry } \\
\text { name }\end{array}$ & Entry & Length & $\begin{array}{l}\text { Nglyc } \\
\mathrm{V} / \mathrm{T}\end{array}$ & Pos & $\begin{array}{l}\text { Oglyc } \\
\text { V/T }\end{array}$ & Pos & Ref \\
\hline CCL1 & P10146 & 92 & $0 / 1$ & 78 & $0 / 1$ & 30 & \\
\hline $\mathrm{CCL} 2$ & P10148 & 148 & $1 / 1$ & 126 & $>1 / 21$ & $\begin{array}{l}97,100,101,105,107,111,112,120,123,128, \\
129,130,132,133,134,135,136,137,138,139, \\
143\end{array}$ & 8 \\
\hline CCL3 & P10855 & 92 & $0 / 0$ & & $0 / 0$ & & \\
\hline CCL4 & P14097 & 92 & $0 / 1$ & 72 & $0 / 0$ & & \\
\hline CCL5 & P30882 & 91 & $0 / 0$ & & $0 / 0$ & & \\
\hline CCL6 & P27784 & 116 & $0 / 0$ & & $0 / 2$ & 102,103 & \\
\hline CCL7 & Q03366 & 97 & $0 / 1$ & 29 & $0 / 0$ & & \\
\hline CCL8 & Q9Z121 & 97 & $0 / 0$ & & $0 / 0$ & & \\
\hline CCL9 & P51670 & 122 & $0 / 1$ & 98 & $0 / 0$ & & \\
\hline CCL11 & P48298 & 97 & $0 / 0$ & & $1 / 0$ & 94 & \\
\hline CCL12 & Q62401 & 104 & $0 / 0$ & & $0 / 2$ & 15,28 & \\
\hline CCL17 & F6R5P4 & 103 & $0 / 0$ & & $0 / 1$ & 6 & \\
\hline CCL19 & 070460 & 108 & $0 / 1$ & 100 & $0 / 5$ & $93,94,101,102,105$ & \\
\hline CCL20 & 089093 & 97 & $0 / 0$ & & $0 / 0$ & & \\
\hline CC21A & P84444 & 133 & $0 / 0$ & & $0 / 6$ & $100,109,110,112,119,125$ & \\
\hline CC21B & P86792 & 133 & $0 / 0$ & & $0 / 6$ & $100,109,110,112,119,125$ & \\
\hline CC21C & P86793 & 133 & $0 / 0$ & & $0 / 7$ & $100,109,110,112,119,125,128$ & \\
\hline CCL22 & 088430 & 92 & $0 / 0$ & & $0 / 1$ & 47 & \\
\hline CCL24 & Q9JKC0 & 119 & $0 / 2$ & 54,115 & $0 / 2$ & 97,105 & \\
\hline CCL25 & 035903 & 144 & $0 / 1$ & 121 & $0 / 12$ & $\begin{array}{l}89,99,101,103,105,110,115,122,123,124, \\
127,129\end{array}$ & \\
\hline CCL26 & F8VQM2 & 93 & $0 / 1$ & 35 & $0 / 0$ & & \\
\hline CCL27 & Q9Z1X0 & 120 & $0 / 1$ & 83 & $0 / 1$ & 103 & \\
\hline CCL28 & Q9JIL2 & 130 & $0 / 1$ & 78 & $0 / 7$ & $88,100,106,114,115,120,123$ & \\
\hline
\end{tabular}


Mouse CXCL

\begin{tabular}{|l|l|l|l|l|l|l|l|}
\hline $\begin{array}{l}\text { Entry } \\
\text { name }\end{array}$ & $\begin{array}{l}\text { PDB } \\
\text { Entry }\end{array}$ & Length & $\begin{array}{l}\text { Nglyc } \\
\text { V/T }\end{array}$ & Pos & $\begin{array}{l}\text { Oglyc } \\
\text { V/T }\end{array}$ & Pos & Ref \\
\hline CXCL1 & P12850 & 96 & $0 / 0$ & & $0 / 0$ & & \\
\hline CXCL2 & P10889 & 100 & $0 / 0$ & & $0 / 0$ & & \\
\hline CXCL3 & Q6W5C0 & 100 & $0 / 0$ & & $0 / 1$ & 56 & \\
\hline CXCL4 & Q9Z126 & 105 & $0 / 0$ & & $0 / 1$ & 31 & \\
\hline CXCL5 & P50228 & 132 & $0 / 0$ & & $0 / 4$ & $2,7,8,13$ & \\
\hline CXCL7 & Q9EQ15 & 113 & $0 / 0$ & & $0 / 0$ & & \\
\hline CXCL9 & P18340 & 126 & $0 / 1$ & 58 & $0 / 5$ & $93,115,118,122,125$ & \\
\hline CXCL10 & P17515 & 98 & $0 / 1$ & 2 & $0 / 0$ & & \\
\hline CXCL11 & Q9JHH5 & 100 & $0 / 0$ & & $0 / 0$ & & \\
\hline CXCL12 & P40224 & 93 & $0 / 0$ & & $0 / 0$ & & \\
\hline CXCL13 & O55038 & 109 & $0 / 0$ & & $0 / 6$ & $92,94,96,97,98,104$ & \\
\hline CXCL14 & Q9WUQ5 & 99 & $0 / 0$ & & $0 / 0$ & & 133, \\
\hline CXCL15 & Q9WVL7 & 167 & $0 / 1$ & 68 & $0 / 3$ & $84,89,139$ & \\
\hline CXCL16 & Q8BSU2 & 246 & $0 / 0$ & & $0 / 20$ & $106,117,118,120,127,129,131,132$, & $137,139,140,143,144,147,151,157,163$, \\
& & & & & & 164,167 & \\
\hline CXCL17 & Q5UW37 & 119 & $0 / 0$ & & $0 / 5$ & $23,31,65,96,100$ & \\
\hline
\end{tabular}

Mouse $\mathrm{XCl}, \mathrm{X} 3 \mathrm{CL}$

\begin{tabular}{|c|c|c|c|c|c|c|c|}
\hline $\begin{array}{l}\text { Entry } \\
\text { name }\end{array}$ & Entry & Length & $\begin{array}{l}\text { Nglyc } \\
\mathrm{V} / \mathrm{T}\end{array}$ & Pos & $\begin{array}{l}\text { Oglyc } \\
V / T\end{array}$ & Pos & Ref \\
\hline XCL1 & P47993 & 114 & $0 / 0$ & & $0 / 8$ & $89,90,97,100,105,106,107,108$ & \\
\hline $\mathrm{X} 3 \mathrm{CL} 1$ & 035188 & 395 & $0 / 1$ & 109 & $0 / 62$ & $\begin{array}{l}97,111,115,118,122,124,127,131,133,142, \\
143,145,151,154,155,163,165,166,168,169, \\
170,178,183,186,193,194,195,199,205,207, \\
208,209,216,218,220,221,222,225,229,230, \\
231,232,234,235,242,255,259,262,270,281, \\
285,290,291,294,296,302,304,316,323,327, \\
332,336\end{array}$ & \\
\hline
\end{tabular}

Human and mouse chemokines were ordered based on cysteines and numbers and according to the IUPAC and international nomenclature. All chemokines were analyzed with protein database (PDB) searches (web link http://www.uniprot.org/). For all chemokines, the PDB entry and the length in amino acids, including the signal peptides, are provided. Next, all molecules were analyzed for the presence of theoretical ( $\mathrm{T}$ ) attachment sites for $\mathrm{N}$-linked and $\mathrm{O}$-linked sugars (web links http://www.cbs.dtu.dk/services/NetNGlyc/ and http://www.cbs.dtu.dk/services/NetOGlyc/). The respective residue positions (Pos) are indicated with their numbers. Finally, the primary literature was controlled to evaluate which attachment sites were experimentally proven to be occupied (indicated in bold red numbers) and the corresponding literature references are provided. For human CCL2 and CCL11 and for mouse CCL11, experimental evidence for an occupied O-linked site exists, whereas this was not theoretically predicted. 
References for Supplemental Table

1. Jiang $\mathrm{Y}$, Valente AJ, Williamson MJ, Zhang L, Graves DT: Post-translational modification of a monocyte-specific chemoattractant synthesized by glioma, osteosarcoma, and vascular smooth muscle cells. J Biol Chem (1990) 265(30):18318-18321.

2. Ruggiero P, Flati S, Di Cioccio V, Maurizi G, Macchia G, Facchin A, Anacardio R, Maras A, Lucarelli M, Boraschi D: Glycosylation enhances functional stability of the chemotactic cytokine CCL2. Eur Cytokine Netw (2003) 14(2):91-96.

3. Kameyoshi Y., Doerschner A., Mallet A.I., Christophers E., Schroeder J.-M.: Cytokine RANTES released by thrombin-stimulated platelets is a potent attractant for human eosinophils. J. Exp. Med. (1992) 176:587-592.

4. Noso N., Bartels J., Mallet A.I., Mochizuki M., Christophers E., Schroeder J.-M.: Delayed production of biologically active O-glycosylated forms of human eotaxin by tumor-necrosis-factor-alphastimulated dermal fibroblasts. Eur. J. Biochem. (1998) 253:114-122.

5. Richter R., Schulz-Knappe P., John H., Forssmann W.-G.: Posttranslationally processed forms of the human chemokine HCC-1. Biochemistry (2000) 39:10799-10805.

6. Halim A., Nilsson J., Ruetschi U., Hesse C., Larson G.: Human urinary glycoproteomics; attachment site specific analysis of $\mathrm{N}$-and O-linked glycosylations by CID and ECD. Mol. Cell. Proteomics (2011) 0:0-0.

7. Nilsson J., Rueetschi U., Halim A., Hesse C., Carlsohn E., Brinkmalm G., Larson G.: Enrichment of glycopeptides for glycan structure and attachment site identification. Nat. Methods (2009) 6:809-811.

8. Ernst CA, Zhang YJ, Hancock PR, Rutledge BJ, Corless CL, Rollins BJ: Biochemical and biologic characterization of murine monocyte chemoattractant protein-1. Identification of two functional domains. J Immunol (1994) 152(7):3541-3549. 